Review

\title{
Measles Virus as an Oncolytic Immunotherapy
}

\author{
Christine E. Engeland $1,2, * \mathbb{C}$ and Guy Ungerechts $1, *$
}

1 Clinical Cooperation Unit Virotherapy, German Cancer Research Center (DKFZ), National Center for Tumor Diseases (NCT) and Department of Medical Oncology, University Hospital Heidelberg, 69120 Heidelberg, Germany

2 Center for Biomedical Education and Research (ZBAF), Institute of Virology and Microbiology, Faculty of Health, School of Medicine, Witten/Herdecke University, 58453 Witten, Germany

* Correspondence: christine.engeland@nct-heidelberg.de (C.E.E.); guy.ungerechts@nct-heidelberg.de (G.U.)

check for updates

Citation: Engeland, C.E.; Ungerechts, G. Measles Virus as an Oncolytic Immunotherapy. Cancers 2021, 13, 544. https://doi.org/

10.3390/cancers13030544

Academic Editor: David Wong

Received: 31 December 2020

Accepted: 26 January 2021

Published: 1 February 2021

Publisher's Note: MDPI stays neutral with regard to jurisdictional claims in published maps and institutional affiliations.

Copyright: (C) 2021 by the authors. Licensee MDPI, Basel, Switzerland. This article is an open access article distributed under the terms and conditions of the Creative Commons Attribution (CC BY) license (https:// creativecommons.org/licenses/by/ $4.0 /)$.
Simple Summary: Measles virus is currently under investigation as an innovative cancer treatment. The virus selectively replicates in and kills cancer cells. Furthermore, it can be genetically engineered to increase tumor specificity and therapeutic efficacy. Importantly, treatment with measles virus activates antitumor immune responses. A number of clinical trials using measles virus for cancer treatment have been completed or are ongoing. Future studies will further harness the possibilities of virus engineering and potential of combination immunotherapies to improve clinical outcome.

Abstract: Measles virus (MeV) preferentially replicates in malignant cells, leading to tumor lysis and priming of antitumor immunity. Live attenuated $\mathrm{MeV}$ vaccine strains are therefore under investigation as cancer therapeutics. The versatile $\mathrm{MeV}$ reverse genetics systems allows for engineering of advanced targeted, armed, and shielded oncolytic viral vectors. Therapeutic efficacy can further be enhanced by combination treatments. An emerging focus in this regard is combination immunotherapy, especially with immune checkpoint blockade. Despite challenges arising from antiviral immunity, availability of preclinical models, and GMP production, early clinical trials have demonstrated safety of oncolytic $\mathrm{MeV}$ and yielded promising efficacy data. Future clinical trials with engineered viruses, rational combination regimens, and comprehensive translational research programs will realize the potential of oncolytic immunotherapy.

Keywords: oncolytic virus; measles virus; cancer immunotherapy; vector engineering; vaccination; immune checkpoint blockade

\section{Introduction-Measles Virus for Cancer Therapy}

Measles virus (MeV) is a negative-strand RNA virus belonging to the family Paramyxoviridae, genus Morbillivirus. Its genome has a length of approximately $16 \mathrm{~kb}$ and encodes six structural and two non-structural proteins (Figure 1a,b). The viral glycoproteins hemagglutinin and fusion mediate receptor binding and fusion at the plasma membrane, respectively. While wild type MeV uses CD150/SLAM on lymphoid cells and epithelial nectin- 4 as receptors, vaccine strains of $\mathrm{MeV}$ infect cells primarily via CD46 [1]. This is due to mutations in the receptor attachment protein hemagglutinin $\mathrm{H}$ in vaccine strain $\mathrm{MeV}$, resulting in high affinity of $\mathrm{H}$ for $\mathrm{CD} 46$ [2-6]. MeV infection results in syncytia formation as typical cytopathic effect (Figure 1c). 
(a)

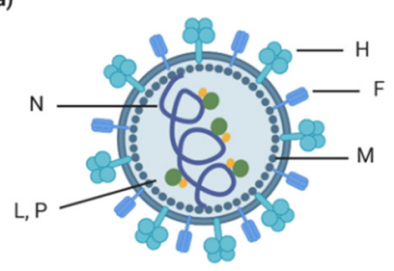

(c)

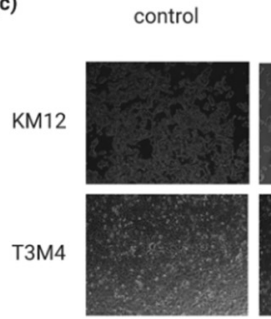

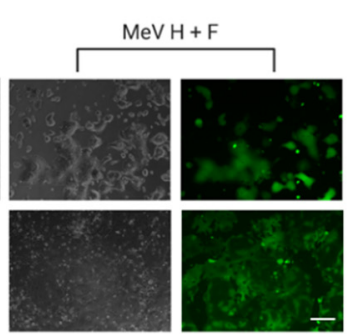

(d)

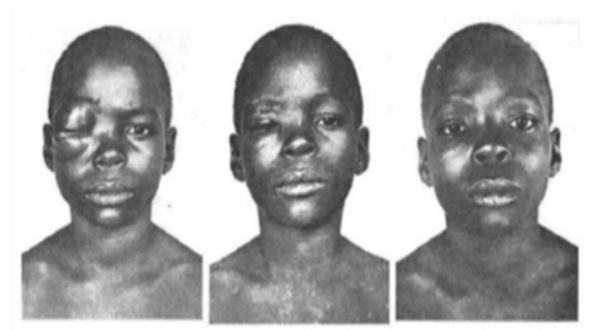

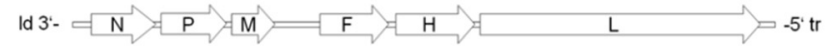

MeV genome (15894 nt)

Figure 1. Measles as an oncolytic virus. (a) Schematic of the measles virus particle. The viral RNA genome is encapsulated by the nucleocapsid $(\mathrm{N})$ protein and is associated with the viral polymerase (L, large protein) and its cofactor phosphoprotein $(\mathrm{P})$, forming the ribonucleoprotein complex (RNP). The matrix (M) protein connects the RNP and the viral envelope. The surface glycoproteins hemagglutinin $(\mathrm{H})$ and fusion $(\mathrm{F})$ mediate receptor binding and cell fusion, respectively. (b) Schematic of the measles virus genome with open reading frames encoding the six structural proteins flanked by the $3^{\prime}$ leader (ld) and $5^{\prime}$ trailer (tr). (c) Syncytia formation as the typical cytopathic effect associated with measles virus infection. Human colorectal cancer (KM12, top) and pancreatic adenocarcinoma (T3M4, bottom) cells were transfected with plasmids encoding the $\mathrm{MeV}$ glycoproteins $\mathrm{H}$ and $\mathrm{F}$ as well as enhanced green fluorescent protein as reporter. Control cells were subjected to mock transfection. Phase contrast and fluorescence images were acquired with an Axiovert 200 microscope (Zeiss) at $36 \mathrm{~h}$ (KM12) and $12 \mathrm{~h}$ post-transfection (T3M4). Scale bar: $200 \mu \mathrm{m}$. (d) Lymphoma remission after measles infection. Left panel: The patient presented with orbital Burkitt's lymphoma. Middle panel: The patient was infected with measles; the typical skin rash is visible. Right panel: Without specific anti-lymphoma treatment, the orbital mass resolved. Reproduced from Lancet 10 July 1971; 2 (7715): 105-106, with permission.

Originally, the idea to treat cancer patients with $\mathrm{MeV}$ arose after case reports which linked measles infection to tumor remission [7]. One highly cited example relates to a boy suffering from Burkitt's lymphoma [8] (Figure 1d). These experiments of nature inspired the idea of using $\mathrm{MeV}$ in cancer treatment. However, measles is a severe infectious disease [9]. Thus, employing a pathogenic strain of $\mathrm{MeV}$ in cancer therapy is out of question. Live attenuated MeV strains for vaccination were licensed in the 1960s and have a proven safety record [10]. Several years later, testing of Edmonston B measles vaccine strain derivatives for cancer treatment began. In many early studies, hematological malignancies were chosen as target entities [11-14]. This was supported by the natural lymphotropism of MeV. However, other malignancies including ovarian cancer [15] and glioblastoma [16] were soon found to also be sensitive to $\mathrm{MeV}$ oncolysis, while normal cells are spared [15,17].

Meanwhile, preclinical efficacy of oncolytic $\mathrm{MeV}$ has been demonstrated against a broad range of cancer entities (reviewed in [18]). In addition to Edmonston B derivatives, also the vaccine strains Moraten-Schwarz [19], Edmonston-Zagreb and AIK-C [20], rMVHu191 [21], as well as Leningrad-16 [22] have been shown to exert oncolytic effects in preclinical studies.

Thus, $\mathrm{MeV}$ is one of several oncolytic platforms currently developed for cancer therapy. Advantages of $\mathrm{MeV}$ include the excellent safety profile of the oncolytic vaccine strains and lack of genotoxicity, its immunogenicity, and especially the plethora of engineering possibilities offered by the $\mathrm{MeV}$ reverse genetics system. Specific challenges related to $\mathrm{MeV}$ include pre-existing antiviral immunity, the choice of preclinical models and manufacturing. These assets and drawbacks are discussed in more detail within this review article.

\section{Measles Virus Oncotropism}

Measles vaccine strain oncotropism correlates with CD46 overexpression on malignantly transformed cells [23]. Although viral entry occurs in benign cells and at low CD46 receptor density, a certain threshold of expression is required for syncytia formation and cell death [24]. In myeloma, CD46 upregulation has been associated with abnormal p53 [25]. The epithelial receptor for MeV, nectin-4 [26,27], is also a tumor marker which 
may render carcinomas of pancreatic [28], colorectal [29], and mammary [30] origin susceptible to $\mathrm{MeV}$ oncolysis. Post-transcriptional regulation of nectin- 4 levels by miR-31 and miR-128 has been demonstrated in breast cancer and glioblastoma [31]. In certain EBV-associated B cell lymphomas, viral latency may promote upregulation of the $\mathrm{MeV}$ receptor CD150/SLAM [32].

On the post-entry level, the cellular interferon (IFN) response has been identified as a key determinant of sensitivity to oncolytic $\mathrm{MeV}$ across several tumor entities, including the NCI60 panel of cancer cell lines [33]. In adult T cell leukemia/lymphoma, resistance to $\mathrm{MeV}$ oncolysis was associated with IFN- $\beta$ production, while sensitive cells did not produce IFN [34]. In mesothelioma and melanoma, effects of treatment with oncolytic $\mathrm{MeV}$ were found not to correlate with CD46 expression, but rather with defects in the IFN response [35,36]. Consistently, expression of retinoic acid inducible gene I (RIG-I) and IFN-induced protein with tetratricopeptide repeats 1 (IFIT1) [37] and IFN-induced transmembrane protein 1 (IFITM1) [38] have been suggested as correlates of relative resistance to $\mathrm{MeV}$ oncolysis. Kurokawa et al. have devised a gene expression signature designating constitutive IFN pathway activation to predict outcome of oncolytic MeV treatment [39]. Further, RSAD2/viperin, encoded by an IFN-stimulated gene (ISG), has been shown to inhibit release of $\mathrm{MeV}$ progeny in ovarian cancer models [40].

Aside from the cellular antiviral response, several additional cellular factors have been associated with sensitivity to $\mathrm{MeV}$ oncolysis. For instance, apoptosis regulators appear to play a role. Caspase 3 has been implicated in MeV-induced cancer cell death [41,42] and overexpression of Bcl-2 reduces $\mathrm{MeV}$-induced cell death in B cell lymphomas [43]. More broadly, basic cellular processes such as protein translation are necessary for efficient $\mathrm{MeV}$ replication and thus tumor cell killing. Stimulating cellular translation by insulin-like growth factor-I (IGF-I) or forced expression of eIF4E increases efficacy of oncolytic MeV, while inhibitors of cap-dependent translation reduce $\mathrm{MeV}$ oncolysis [44]. Furthermore, it has been reported that integrity of lipid rafts is a prerequisite for oncolysis with the MV-Hu191 strain [21]. Determinants of MeV oncotropism are summarized in Figure 2.
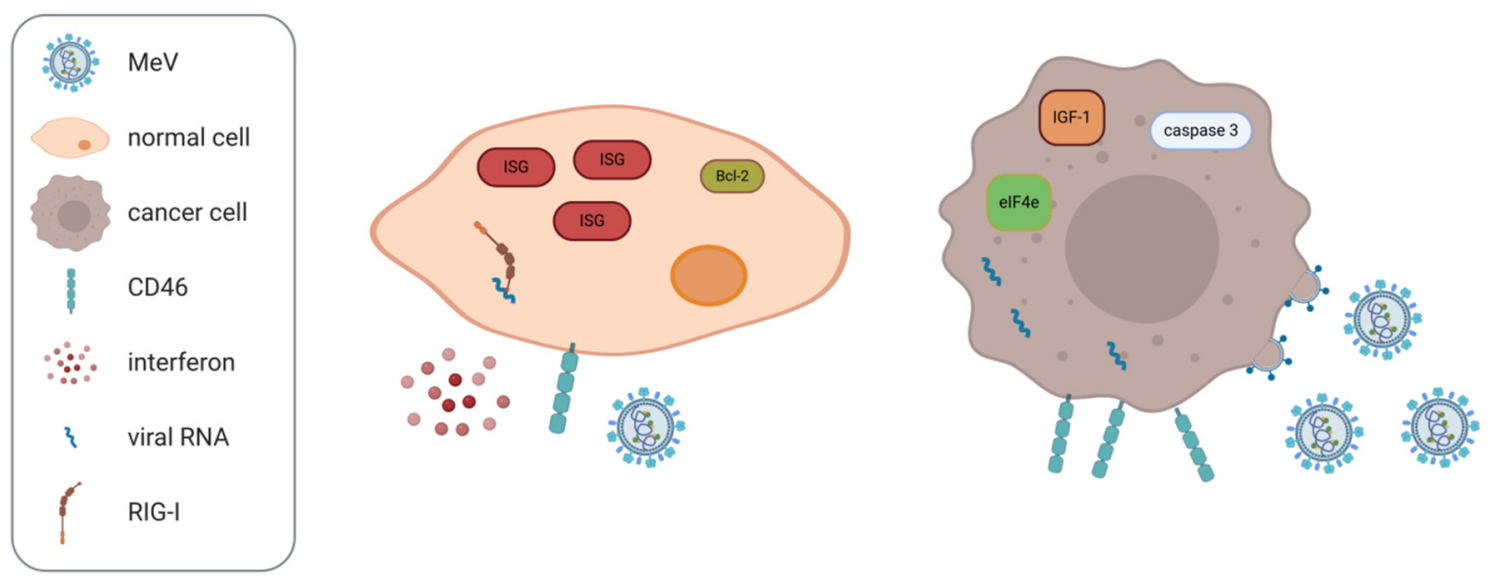

Figure 2. Measles virus oncotropism. Oncolytic measles virus $(\mathrm{MeV})$ does not replicate productively in normal cells (left) in contrast to cancer cells (right). This oncotropism has been associated with differential expression of i.a. the depicted host cells factors. ISG: interferon-stimulated gene; RIG-I: retinoic acid-inducible gene I; IGF-1: insulin-like growth factor-I.

Overall, oncolytic $\mathrm{MeV}$ acts via mechanisms distinct from other established cancer treatments. Accordingly, gemcitabine-resistant pancreatic adenocarcinoma cells are susceptible to MeV oncolysis [45] and chemotherapy-induced senescence does not abrogate oncolysis [46].

\section{Combination Therapies}

Nevertheless, monotherapy with oncolytic MeV will often be insufficient to cure advanced stage malignancies. Modern medical oncology builds on effective combination 
therapies. Therefore, measles virotherapy has been combined with other established cancer therapies such as radiation and chemotherapy (recently reviewed in [47]). Synergistic effects of oncolytic $\mathrm{MeV}$ and radiotherapy against glioblastoma were observed in vitro and in a xenograft model [48]. In vitro studies have also demonstrated successful combination of oncolytic $\mathrm{MeV}$ with chemotherapies such as paclitaxel [49], camptothecin [50], and gemcitabine [51]. Combination with the anti-epidermal growth factor receptor (EGFR) monoclonal antibody nimotuzumab was reported to result in increased antitumor efficacy in laryngeal cancer models [52].

Several small molecules have also been shown to enhance $\mathrm{MeV}$ oncolysis by modulating host cell factors. MeV infection is associated with heat shock protein (Hsp) 70 upregulation. Combination treatment with a Hsp90 inhibitor, resulting in increased Hsp70 expression [53,54], led to increased apoptosis [55]. Counteracting the IFN response, e.g., with janus-associated kinase (JAK) inhibitors such as ruxolitinib, enhances $\mathrm{MeV}$ replication in vitro [56]. Epigenetic modulation by histone deacetylase (HDAC) inhibition was also reported to increase efficacy of oncolytic $\mathrm{MeV}$ by preventing induction of ISGs in hepatocellular carcinoma [57], but by a different, so far unresolved mechanism in pancreatic adenocarcinoma [58]. As MeV spread and syncytia formation involves remodeling of the actin cytoskeleton, inhibition of Rho-associated coiled-coil forming kinase (ROCK) was tested during treatment of prostate, breast, and glioblastoma cancer cells with $\mathrm{MeV}$, yielding increased viral replication, spread, and tumor cell killing [59]. Compounds which modulate cellular metabolism have also been tested in combination approaches. Blocking aerobic glycolysis with dichloroacetate was shown to increase cell death upon $\mathrm{MeV}$ treatment [60]. Furthermore, inducing autophagy has been suggested as a combination strategy to promote $\mathrm{MeV}$ oncolysis [61].

Even combination with other oncolytic viruses is conceivable. Along these lines, the combination of $\mathrm{MeV}$ with mumps virus showed increased efficacy in a human prostate cancer xenograft model [62].

\section{Engineering Oncolytic MeV}

Purposeful modification of oncolytic $\mathrm{MeV}$ vectors to enhance virotherapy was enabled by development of a reverse genetics system for rescue of $\mathrm{MeV}$ from cloned cDNA [63]. This system allows for insertion of transgenes via additional transcription units equipped with $\mathrm{MeV}$ polymerase regulatory sequences [64]. These genes are then expressed in infected cells, i.e., within the tumor. A plethora of genetic engineering approaches has been pursued which are summarized in the following, and in Figure 3 (for recent reviews, see $[47,65]$ ).

\subsection{Tracking Viral Replication and Spread}

Initially, reporter genes were inserted for tracking of $\mathrm{MeV}$ replication. Carcinoembryonic antigen (CEA) and $\beta$-human chorionic gonadotropin (HCG) were selected, which can be measured in routine clinical laboratory testing [12]. Encoding the sodium iodide symporter, NIS, yielding MV-NIS, allowed for $\gamma$-camera imaging of iodine-123 $\left({ }^{123} \mathrm{I}\right)$ or $99 \mathrm{~m}$ technetium uptake and also radiotherapy with ${ }^{131} \mathrm{I}$ [66]. In later studies, MV-NIS was used for advanced imaging techniques, such as pinhole micro-single photon emission computed tomography/computed tomography (SPECT/CT) [67] and contrast-enhanced CT [68]. Recently, a recombinant $\mathrm{MeV}$ variant encoding a fluorescent reporter gene was used for intravital imaging of viral spread at single-cell resolution by two-photon microscopy [69].

Data from preclinical studies with MV-NIS have also been used to develop mathematical models of oncolytic virotherapy and its combinations. This has been devised as a means to rationalize testing of distinct dosing and scheduling regimens [70-73]. 


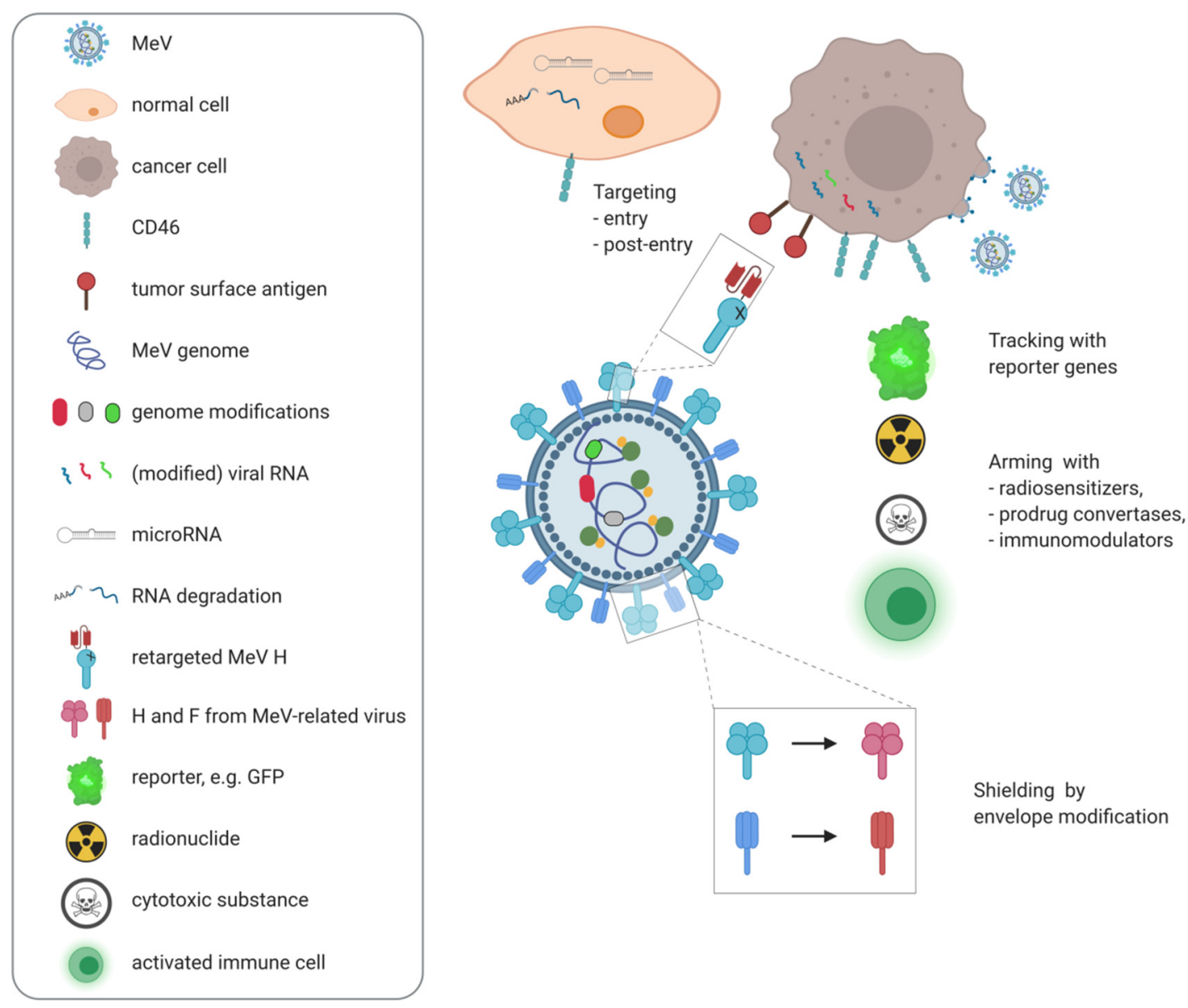

Figure 3. Engineering of oncolytic measles virus. Top: Targeting for increased tumor specificity can be achieved on the entry or post-entry level. For entry targeting, the viral attachment protein $\mathrm{H}$ can be mutated to ablate natural tropism and redirected by fusing targeting moieties such as antibody single-chain variable fragments to $\mathrm{H}$ (red). Post-entry targeting is achieved via target sites for microRNAs (gray) introduced into viral genes which are differentially expressed in malignant compared to healthy tissues, leading to degradation of the respective viral RNAs in normal cells. Middle: Viruses equipped with reporter genes encoding, e.g., fluorescent proteins (light green) can be used to track viral spread. To increase therapeutic efficacy, viruses can be armed with additional genes encoding radiosensitizers, prodrug convertases, or immunomodulators. Bottom: Shielding against neutralizing antibodies can be achieved by exchanging the viral envelope proteins for the counterparts from a related virus.

Valuable information was gained by employing viruses with reporter genes in clinical trials. After intraperitoneal administration of MV-CEA, dose-dependent increases in CEA levels were measured in peritoneal fluid and serum [74]. After intraperitoneal administration of MV-NIS, ${ }^{123}$ I SPECT/CT scans were positive in three of 13 ovarian cancer patients, confirming viral gene expression at the tumor site. Scans were positive in eight of 31 multiple myeloma patients receiving MV-NIS i.v. [75]. In both studies, positive scans were associated with higher virus doses.

\subsection{Retargeting $\mathrm{MeV}$}

Virus engineering has not only enabled tracking viral spread, but also modifying its tropism to increase tumor specificity. Retargeting of $\mathrm{MeV}$ was accomplished by mutating the intrinsic receptor binding sites and fusing antibody single-chain variable fragments $(\mathrm{scFv})$ to the C-terminus of the viral hemagglutinin [76]. Using this strategy, oncolytic $\mathrm{MeV}$ were targeted to the myeloma surface antigen CD38 [13], to CD20 for targeting of B cell malignancies [77], folate receptor (FR)- $\alpha$ for treatment of ovarian cancer [78], and EGFRvIII expressed in glioblastoma [79], among others (reviewed in [18]). A range of different 
targeting moieties beyond $\mathrm{scFv}$ has been employed, such as the cytokine interleukin (IL)13 [80] or the urokinase plasminogen activator [81] for direction of viral tropism to their respective receptors. Successful targeting has also been achieved using integrin-binding peptides [82], DARPins [83] and cystine knot proteins [84]. Viral tropism can be redirected to specific cell populations within the tumor, including tumor-initiating cells [85], the tumor stroma [86], and vasculature [81].

A sophisticated means of viral entry targeting employs proteases expressed within the tumor microenvironment. The $\mathrm{MeV}$ fusion protein encompasses a furin cleavage site and requires proteolytic processing for activity. Replacing the furin cleavage site with sequences recognized by matrix metalloproteinases or the urokinase-type plasminogen activator can increase tumor specificity $[87,88]$.

Tumor targeting on the post-entry level was achieved using microRNA target sites inserted into the untranslated regions (UTRs) of viral genes [89]. This concept exploits downregulation of specific microRNAs in malignant vs. benign cells, leading to virus restriction in healthy tissue while spread within tumor tissue is unimpaired.

Proof-of-concept was also obtained for using riboswitches to control oncolytic MeV. Insertion of a ligand-activated ribozyme into the UTR of the $\mathrm{MeV}$ fusion gene enabled regulation of $\mathrm{MeV}$ infectivity and spread by addition of the cognate small molecule [90]. Recently, a photocontrollable $\mathrm{MeV}$ variant was reported which harbors a split L protein for control of viral replication by blue light illumination [91].

\subsection{Arming with Additional Therapeutic Genes}

While these means of targeting aim at enhancing specificity of virotherapy, a number of genetic engineering approaches have been developed to increase antitumor efficacy, often referred to as "arming". First arming strategies aimed at inducing bystander effects in combination radiotherapy and chemotherapy approaches. As mentioned above, MV-NIS allows for concentration of radioactive iodine in infected tumor cells [66].

$\mathrm{MeV}$ vectors encoding prodrug convertases were designed for local conversion of prodrugs into active chemotherapeutics. $\mathrm{MeV}$ encoding the purine nucleoside phosphorylase, which converts fludarabine into 2-fluoroadenine and 6-methylpurine-2'-deoxyriboside (MeP-dR) to 6-methylpurine, respectively, combined with prodrug administration improved outcome in lymphoma xenograft and immunocompetent murine colorectal cancer models [92,93]. Analogously, MeV was engineered to encode super cytosine deaminase (SCD), a fusion protein of yeast cytosine deaminase and yeast uracil phosphoribosyltransferase, which converts the prodrug 5-fluorocytosine (5-FC) to 5-fluorouracil (5-FU) [94-97].

Other engineering approaches to increase anti-tumor efficacy include insertion of a transgene encoding the proapoptotic protein BNiP3 [49] and the angiogenesis inhibitors endostatin and angiostatin to remodel the tumor microenvironment [98].

\section{Immunovirotherapy}

While early efforts in engineering oncolytic $\mathrm{MeV}$ mainly focused on maximizing direct tumor cell killing, there has been a recent shift from mainly oncolytic to mainly immunotherapeutic treatment strategies, spurred by the developments in cancer immunotherapy which have revolutionized medical oncology.

$\mathrm{MeV}$ oncolysis per se has pleiotropic effects on the anti-tumor immune response and supports all phases of the "cancer immunity cycle" (Figure 4; reviewed in [99]). MeVinduced cell death is immunogenic [100], induces a distinctive immunopeptidome [101], and promotes cross-priming of antitumor $\mathrm{T}$ cell responses by conventional and plasmacytoid dendritic cells $[19,102]$. MeV oncolysis has also been reported to increase tumor necrosis factor-related apoptosis-inducing ligand (TRAIL)-mediated cytotoxicity by myeloid and plasmacytoid DCs [103] as well as modulation of macrophages towards an antitumor phenotype [104]. Neutrophil activation also occurs, leading to secretion of IL-8, tumor necrosis factor (TNF)- $\alpha$, monocyte chemoattractant protein (MCP)-1, and IFN- $\alpha$, TRAIL 
expression, and degranulation [105], which may be beneficial or not depending on the tumor model [106].

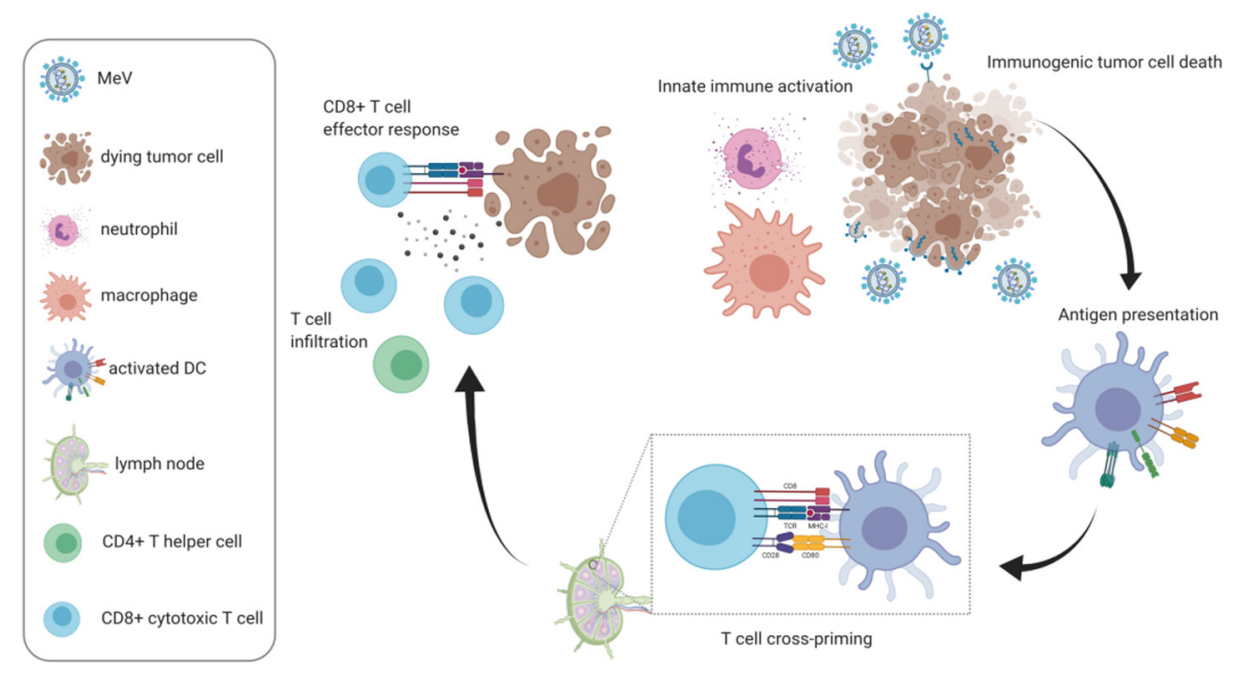

Figure 4. Measles virus as an oncolytic immunotherapy. Measles virus-mediated oncolysis has been shown to support different phases of the antitumor immune response: Oncolysis induces immunogenic cell death, which promotes dendritic cell activation, antigen presentation, and crosspriming of T cells. Measles virotherapy remodels the tumor microenvironment, thereby enhancing innate (macrophage repolarization and neutrophil degranulation) as well as adaptive antitumor immunity (T cell infiltration and CD8+ effector responses).

These immunotherapeutic effects can be enhanced by insertion of immunomodulatory transgenes into the $\mathrm{MeV}$ genome (Table 1). Further, $\mathrm{MeV}$ can serve as a vector to deliver immunomodulators to the tumor site which can be highly toxic when administered systemically. The first immunomodulatory transgene reported in the context of many oncolytic viruses and also $\mathrm{MeV}$ was the granulocyte macrophage colony stimulating factor, GM-CSF [14]. In a lymphoma xenograft model, MV GM-CSF led to increased neutrophil infiltration, which correlated with tumor regression. Further immunomodulators have been shown to increase innate immune activation in the context of $\mathrm{MeV}$ oncolysis. A $\mathrm{MeV}$ vector encoding IFN- $\beta$ was reported to induce immune infiltration and remodeling of the tumor microenvironment in mesothelioma xenografts [107]. MeV encoding the immunomodulatory neutrophil-activating protein (NAP) of H. pylori prolonged survival and induced a beneficial cytokine response in breast cancer xenograft pleural effusion and lung colonization models [108].

Introduction of the first fully immunocompetent mouse model of $\mathrm{MeV}$ oncolysis, MC38cea [93], was the prerequisite to further study immunomodulatory $\mathrm{MeV}$ vectors and demonstrate induction of tumor-specific adaptive immune responses. This model consists of murine colorectal adenocarcinoma MC38, syngeneic to C57BL/6 mice and stably expressing the carcinoembryonic antigen (CEA), which are susceptible to CEA-targeted $\mathrm{MeV}$ [93]. In this model, treatment with MV GM-CSF led to prolonged survival compared to control MV. Forty percent of treated mice experienced complete tumor remission and were subsequently protected from tumor re-engraftment, indicating a tumor vaccination effect. Further, treatment with MV GM-CSF enhanced intratumoral T cell infiltration as well as tumor-specific T cell responses [109]. 
Table 1. Immunomodulatory oncolytic MeV. Overview of immunomodulatory transgenes that have been encoded in $\mathrm{MeV}$, their anticipated immunological effects in the context of $\mathrm{MeV}$ oncolytic immunotherapy, and the outcome of the respective preclinical studies. GM-CSF: granulocyte-macrophage colony-stimulating factor; IFN: interferon; NAP: neutrophil activating protein; CTLA-4: cytotoxic T lymphocyte antigen-4; PD-L1: programmed cell death 1-ligand 1; Th: T helper cell; $\mathrm{T}_{\text {eff }}$ : effector T cell; $\mathrm{T}_{\text {reg: }}$ regulatory $\mathrm{T}$ cell; IL: interleukin; AICD: activation-induced cell death; BiTE: bispecific T cell engager; TAA: tumor-associated antigen; IFNAR: IFN- $\alpha$ receptor.

\begin{tabular}{|c|c|c|}
\hline Immunomodulator & Anticipated Immunological Effects & Preclinical Data \\
\hline GM-CSF & $\begin{array}{c}\text { Dendritic cell activation and maturation; } \\
\text { activation of monocytes, macrophages, } \\
\text { neutrophils, NK cells }\end{array}$ & $\begin{array}{l}\text { SCID model: increased antitumor efficacy, } \\
\text { increased neutrophil infiltration [14] } \\
\text { Immunocompetent model: increased antitumor } \\
\text { efficacy, increased T cell infiltration, stronger } \\
\text { tumor-specific T cell responses, rejection of } \\
\text { tumor re-engraftment [109] }\end{array}$ \\
\hline IFN- $\beta$ & $\begin{array}{l}\text { Enhanced antitumor response via innate } \\
\text { and adaptive effector mechanisms }\end{array}$ & $\begin{array}{c}\text { Athymic nude mouse model: increased CD68+ } \\
\text { macrophage infiltration, reduced microvessel } \\
\text { density; delayed tumor progression, prolonged } \\
\text { survival [107] }\end{array}$ \\
\hline H. pylori NAP & $\begin{array}{l}\text { Inflammatory response, promotion of } \\
\text { Th1-polarized immune responses }\end{array}$ & $\begin{array}{l}\text { Athymic nude mouse model: prolonged survival, } \\
\text { neutrophil infiltration, secretion of } \\
\text { Th1-promoting cytokines [108] }\end{array}$ \\
\hline Anti-CTLA-4, anti-PD-L1 & Enhanced antitumor $\mathrm{T}$ cell response & $\begin{array}{l}\text { Immunocompetent mouse model: delayed } \\
\text { tumor progression, prolonged survival, } \\
\text { increased } \mathrm{T}_{\text {eff }} / \mathrm{T}_{\text {reg }} \text { ratio, increased } \\
\text { tumor-specific IFN- } \gamma \text { response [110] }\end{array}$ \\
\hline IL-12 & $\begin{array}{l}\text { Activation and recruitment of T cells and } \\
\text { NK cells }\end{array}$ & $\begin{array}{c}\text { Immunocompetent mouse model: increased } \\
\text { survival rates (CD8+-dependent), rejection of } \\
\text { tumor re-engraftment, increased tumor-specific } \\
\text { IFN- } \gamma \text { response, expression of effector cytokines, } \\
\text { increased T cell infiltration, decrease in NK cells, } \\
\text { increased proportion of activated CD8+ T cells } \\
\text { and NK cells [111] }\end{array}$ \\
\hline IL-15 superagonist & $\begin{array}{c}\text { Activation of T cells and NK cells without } \\
\text { induction of AICD }\end{array}$ & $\begin{array}{l}\text { Immunocompetent mouse model: increased } \\
\text { CD8+ T cell and NK cell infiltration and } \\
\text { activation, antitumor efficacy inferior to } \mathrm{MeV} \\
\text { encoding IL-12 [112] }\end{array}$ \\
\hline BiTEs & $\begin{array}{l}\text { Recruitment of T cells, enhanced T cell } \\
\text { antitumor cytotoxicity }\end{array}$ & $\begin{array}{c}\text { Immunocompetent mouse model: increased T } \\
\text { cell infiltration, prolonged survival, induction of } \\
\text { tumor-specific immunity } \\
\text { Patient-derived xenograft models: prolonged } \\
\text { survival [113] }\end{array}$ \\
\hline TAA & $\begin{array}{l}\text { Priming and activation of TAA-specific T } \\
\text { cells }\end{array}$ & $\begin{array}{l}\text { IFNAR }{ }^{-/-} \text {CD46 transgenic mouse model: } \\
\text { Induction of humoral and cellular responses } \\
\text { against TAA, reduced tumor nodules and } \\
\text { prolonged survival in lung colonization } \\
\text { experiment [114] } \\
\text { Ex vivo assays: Priming and activation of } \\
\text { TAA-specific T cells [115] }\end{array}$ \\
\hline
\end{tabular}

Italic: bacterial taxa.

To develop a second immunocompetent model of MeV oncolysis in C57BL/6 mice, B16 melanoma cells were transduced for stable expression of the CD20 surface antigen for treatment with CD20-targeted $\mathrm{MeV}$. In this model, $\mathrm{MeV}$ vectors encoding immune checkpoint antibodies against cytotoxic T lymphocyte-associated-4 (CTLA-4) and programmed cell death-ligand 1 (PD-L1) prolonged survival compared to MeV encoding the antibody constant region only [110]. Combination with systemically administered antibodies against CTLA-4, PD-1, and PD-L1 has also demonstrated the therapeutic value 
of this approach $[110,116]$. In the MC38cea model, systematic comparison of transgenes targeted at different phases of the cancer immunity cycle-GM-CSF, IFN- $\gamma$ induced protein 10 (IP-10), membrane-bound CD80, anti-CTLA-4, IL-12, and anti-PD-L1 identified the latter two as the most potent [111]. MeV encoding IL-12 induced complete tumor remissions in $90 \%$ of treated mice, which were mediated by CD8+ effector T cell responses. Oncolytic $\mathrm{MeV}$ vectors encoding an IL-15 superagonist mediated T and NK cell activation, but were less effective than MeV encoding IL-12 [112]. Bispecific T cell engagers (BiTEs) simultaneously bind CD3 on T cells and a tumor surface antigen, thereby redirecting $\mathrm{T}$ cells to tumor cells to mediate antitumor $\mathrm{T}$ cell cytotoxicity. Oncolytic measles viruses encoding BiTEs were shown to promote $\mathrm{T}$ cell infiltration and activation in syngeneic and patient-derived tumor models [113].

For induction of $\mathrm{T}$ cell responses against specific antigens, $\mathrm{MeV}$ can also be employed as a heterologous, highly immunogenic vaccine vector (reviewed in [117]). This strategy has been used to develop vaccines against a range of pathogens, including emerging SARS CoV-2 [118]. This strategy has been adopted in oncolytic immunotherapy by encoding tumor-associated antigens in the $\mathrm{MeV}$ vector. $\mathrm{MeV}$ vectors encoding ovalbumin (OVA) as model antigen or the tumor antigen claudin- 6 either in native form or in association with lentivirus-like particles were shown to induce antigen-specific humoral and cellular immune responses in IFN- $\alpha$ receptor (IFNAR)-deficient, CD46-transgenic mice and prolong survival in B16-derived tumor models [114]. Employing OVA and the melanoma antigen tyrosinase-related protein-2 (TRP-2), MeV vectors encoding the full-length antigens or their respective immunodominant CD8+ epitope or epitope variants were generated. The epitope variants are either secreted or targeted to the proteasome. Using these $\mathrm{MeV}$ vectors, activation and dendritic cell-mediated priming of cognate T cells was demonstrated ex vivo [115].

As another modality of immunovirotherapy, combination of oncolytic MeV with adoptive transfer of antitumor immune effector cells such as NK cells [119] or CD8+ NKG2D+ cells [120] has been reported.

Importantly, antitumor immune activation by $\mathrm{MeV}$ oncolysis has not only been demonstrated in preclinical models. Clinical data also suggest augmentation of antitumor immunity by oncolytic measles virotherapy. In cutaneous $\mathrm{T}$ cell lymphoma, a shift towards a Th1-biased $\mathrm{T}$ cell population in lymphoma lesions was noted after treatment [121]. In four ovarian cancer patients treated with MV-NIS, IFN- $\gamma$ and IL-4 responses against the tumor antigens FR $\alpha$ and IGF binding protein 2 (IGFBP2) were detected by ELISPOT [122]. Increases in IFN- $\gamma$ ELISPOT counts against cancer testis antigens were also observed in the majority of tested multiple myeloma patients treated with MV-NIS [123]. The myeloma patient with an exceptional response to MV-NIS had a high mutational load and high baseline $\mathrm{T}$ cell responses against several tumor antigens, which remained stable after virotherapy.

Of note, the clinical trials published thus far tested oncolytic MeV not encoding any additional immunotherapeutic payloads. Perhaps the fraction of patients showing immunological responses and overall therapeutic efficacy can be increased with novel immunomodulatory oncolytic MeV.

\section{Antitumor vs. Antiviral Immunity}

However, immune stimulation in the context of oncolytic virotherapy may hamper overall efficacy by premature viral clearance [124]. Though conferring a safety advantage, the antiviral immune response and specifically high measles seropositivity in the general population is one of the main reservations against using $\mathrm{MeV}$ for oncolytic virotherapy. Therefore, multiple strategies have been devised to circumvent anti-viral immunity. Substitution of the $\mathrm{P} / \mathrm{V} / \mathrm{C}$ and also $\mathrm{N}$ and $\mathrm{L}$ genes of attenuated oncolytic strains for their wild type counterparts has been shown to dampen the cellular IFN response and increase viral spread $[125,126]$. These variants resulted in higher progeny titers, increased viral gene expression, and cell killing in presence of interferon or in interferon-competent cells. Mutation of common antibody epitopes in the $\mathrm{MeV}$ envelope glycoproteins allows for 
evasion of virus neutralization in serum [127]. By exchanging the glycoproteins for their counterparts from a related morbillivirus, canine distemper virus, an envelope chimeric $\mathrm{MeV}$ was generated which showed similar replication kinetics and oncolytic properties as unmodified $\mathrm{MeV}$, but was not neutralized by human MeV-immune sera [128]. However, these approaches may compromise safety. As alternatives, different "shielding" approaches have been developed to protect oncolytic $\mathrm{MeV}$ from antibody-mediated clearance.

One approach is to employ cell carriers to "deliver" oncolytic MeV to the tumor site. Successful tumor delivery by heterofusion of infected carrier cells and tumor cells was first demonstrated for infected monocytes, endothelial cells, and stimulated human peripheral blood cells. This allowed for effective oncolysis after i.v. or i.p. administration after passive immunization in xenograft models [129]. A range of different cell types have been employed as carriers, including T cells [130], cytokine-induced killer cells [131], mesenchymal stem cells [132], mesenchymal stromal cells [133], and also irradiated myeloma cells [134].

As an acellular shield, the scavenger receptor ligand polyinosinic acid can be used to prevent $\mathrm{MeV}$ sequestration by hepatic Kupffer cells after i.v. administration [135]. This was shown to enhance oncolytic efficacy in a nude mouse model. Multi-layer coating with ionic polymers and graphene oxide sheets [136] have also been reported as a means to protect $\mathrm{MeV}$ from premature clearance [137]. These modifications did not compromise infection of tumor cells and even enhanced oncolytic effects. Administration of UV-inactivated MeV as a decoy virus has been suggested as a means to sequester antiviral antibodies prior to treatment [138].

Instead of modifying the oncolytic agent, immune modulation in the patient has been envisaged to enable measles virotherapy. Clinically approved multidose cyclophosphamide regimens were shown to dampen both primary and secondary antibody responses to $\mathrm{MeV}$ [139]. Although pre-existing immunosuppression in advanced stage cancer and especially low antibody levels in myeloma patients were anticipated, cyclophosphamide was also tested in one cohort of the Phase I trial of MV-NIS for advanced multiple myeloma [75]. Clinical data in this regard are still limited, but so far no clear correlation between antimeasles immunity and therapeutic efficacy has been noted.

\section{Preclinical Models}

The conundrum of balancing antiviral immunity and antitumor immunity exemplifies the challenge to identify appropriate models for preclinical development of oncolytic $\mathrm{MeV}$. Measles is a primate-adapted virus, thus rodents and other small animals commonly used in research are non-susceptible to the virus. CD46-transgenic, IFNAR-knockout (IFNAR ${ }^{-/-}$CD46Ge) mice which are supposed to mimic $\mathrm{MeV}$ replication and spread in humans are commonly used for study of $\mathrm{MeV}$ vaccines [117] and have also been used for testing of oncolytic $\mathrm{MeV}$ vaccines [114]. However, it remains unclear how the IFNAR ${ }^{-/-}$ phenotype affects outcome of virotherapy. Syngeneic transplantable tumor models in fully immunocompetent mice have been widely adopted [99]. While these models have enabled proof-of-concept studies, they fail to recapitulate the genetic makeup, heterogeneity and evolution of human cancers. To address these issues, human precision cut liver slices [20], clinical samples [140], and patient-derived xenografts [113] have been used in preclinical testing of measles virotherapy. Successful targeting of cancer-initiating cells in patient-derived cultures, including glioma stem cells from neurospheres [141] and colorectal cancer tumor spheroids [85] have been reported. To address specific tumor niches, orthotopic models such as breast cancer pleural effusion [142] and intracranial glioblastoma models $[116,141]$ have been studied, demonstrating efficacy of oncolytic $\mathrm{MeV}$ also in advanced preclinical models.

\section{Pharmacokinetics and-Dynamics}

In preparation of clinical trials, several preclinical toxicology and pharmacokinetic studies have been carried out in mice and non-human primates [143-147]. These studies confirmed safety of intravenous injection of up to $10^{8}$ and $4 \times 10^{8} \mathrm{TCID}_{50} / \mathrm{kg}$ oncolytic 
$\mathrm{MeV}$ in IFNAR $^{-/-} \mathrm{CD} 46 \mathrm{Ge}$ and squirrel monkeys, respectively. Further, intraventricular injection of oncolytic $\mathrm{MeV}$ into the cerebrospinal fluid of IFNAR ${ }^{-/-}$CD46Ge mice [147] and intrahepatic injection of prodrug convertase-armed oncolytic $\mathrm{MeV}$ in IFNAR ${ }^{-/-}$ CD46Ge mice and rhesus macaques [146] were tolerated. Depending on the model, different pharmacokinetics and dose-response relationships were observed. Notably, despite detection of viral RNA, no significant shedding of infectious virus was reported.

This holds true in clinical settings. Saliva and urine samples were free of infectious virus after i.p. administration of MV-CEA in ovarian cancer patients [74]. Up to $10^{9} \mathrm{TCID}_{50}$ i.p. and $10^{11} \mathrm{TCID}_{50}$ i.v. have been administered with manageable side effects $[75,122]$. The available clinical data also suggest a dose-response relationship, with higher doses associated with more favorable outcome.

\section{Early Clinical Trials with $\mathrm{MeV}$}

Clinical trials in oncology typically enroll patients after failure of established therapies. In the first clinical trial with oncolytic $\mathrm{MeV}$, patients with therapy-resistant or relapsed cutaneous $\mathrm{T}$ cell lymphomas received intralesional injections of Edmonston-Zagreb measles vaccine. As a safety measure, IFN- $\alpha$ was administered prior to treatment. Treatment was well tolerated and tumor regressions, also of non-injected lesions, were observed. Serial biopsies showed intralesional viral replication and favorable changes in the intralesional $\mathrm{T}$ cell populations [121].

Quite a high number of subsequent trials were conducted at Mayo Clinic in patients with very different cancer entities including ovarian cancer [74,122] (NCT02068794; NCT00390299), glioblastoma multiforme (NCT00390299), medulloblastoma (NCT02962167), mesothelioma (NCT01503177), breast cancer (NCT04521764), head and neck squamous cell carcinoma (NCT01846091), malignant peripheral nerve sheath tumors (NCT02700230), bladder cancer (NCT03171493), and multiple myeloma (NCT00450814; NCT02192775) using Edmonston B-derived attenuated MeV. These Phase I/II trials showed that MeV administration through all investigated routes including intraperitoneal, intracranial, intratumoral, intrapleural, and intravenous administration is safe, feasible, and may lead to a favorable outcome compared to expected median survival in the treated patient population $[74,122]$. In patients with multiple myeloma, treatment with oncolytic MeV led to transient drops in serum free light chains as myeloma marker in several patients. One patient experienced a durable complete remission which is still ongoing to date $[75,148]$.

\section{Translational Considerations, Perspectives, and Conclusions}

As a consequence of the observed dose-response relationships, highest feasible doses are administered in current trials. However, large-scale manufacturing of the required hightiter, highly purified good manufacturing practice (GMP)-grade recombinant $\mathrm{MeV}$ remains challenging [149], despite development of processes including production in serum-free cell culture, tangential flow filtration, and diafiltration [150-152]. Nevertheless, these efforts seem worthwhile, given the versatility of $\mathrm{MeV}$ as an oncolytic vector platform [47], the excellent safety record of $\mathrm{MeV}$ vaccines [10], as well as the biosafety profile [153] and genetic stability [154] of recombinant $\mathrm{MeV}$.

As outlined above, several rational combination approaches to cancer immunovirotherapy employing $\mathrm{MeV}$ and different immunomodulators will be under clinical investigation in the future. Other OVs have already been combined successfully with immune checkpoint inhibitors [155] in clinical trials. Moreover, clinical translation of second-generation $\mathrm{MeV}$ engineered to encode relevant immunomodulators as illustrated above will most likely further improve clinical outcomes.

Moving forward in this direction, it will be decisive to validate predictive markers of response and resistance in a clinical setting. These markers should not only incorporate tumor cell characteristics, but also signatures of antitumor immune activation. By defining criteria of successful immunovirotherapy, these results will also assist in prioritizing the most effective therapeutic payloads and combination therapies. Towards this end, even 
early stage clinical trials must encompass comprehensive correlative research programs to accelerate the advancement of effective immunovirotherapies.

Author Contributions: Conceptualization, C.E.E. and G.U.; writing—original draft preparation, C.E.E.; writing - review and editing, G.U. and C.E.E.; visualization, C.E.E. All authors have read and agreed to the published version of the manuscript.

Funding: This research received no external funding.

Institutional Review Board Statement: Not applicable.

Informed Consent Statement: Not applicable.

Acknowledgments: We acknowledge Gemma Pidelaserra Martí and Johannes Heidbuechel for comments on the draft manuscript. We thank Alessia Floerchinger for providing micrographs for Figure 1c. Graphical abstract, Figures 1a, 2-4 were created with Biorender.com.

Conflicts of Interest: C.E.E. and G.U. are listed as inventors on patent applications related to the use of measles viruses for cancer immunotherapy. G.U. acts as CMO, CSO, and COO of CanVirex.

\section{References}

1. Lin, L.T.; Richardson, C.D. The Host Cell Receptors for Measles Virus and Their Interaction with the Viral Hemagglutinin (H) Protein. Viruses 2016, 8, 250. [CrossRef] [PubMed]

2. Lecouturier, V.; Fayolle, J.; Caballero, M.; Carabaña, J.; Celma, M.L.; Fernandez-Munoz, R.; Wild, T.F.; Buckland, R. Identification of two amino acids in the hemagglutinin glycoprotein of measles virus (MV) that govern hemadsorption, HeLa cell fusion, and CD46 downregulation: Phenotypic markers that differentiate vaccine and wild-type MV strains. J. Virol. 1996, 70, 4200-4204. [CrossRef] [PubMed]

3. Hsu, E.C.; Sarangi, F.; Iorio, C.; Sidhu, M.S.; Udem, S.A.; Dillehay, D.L.; Xu, W.; Rota, P.A.; Bellini, W.J.; Richardson, C.D. A single amino acid change in the hemagglutinin protein of measles virus determines its ability to bind CD46 and reveals another receptor on marmoset B cells. J. Virol. 1998, 72, 2905-2916. [CrossRef]

4. Seki, F.; Takeda, M.; Minagawa, H.; Yanagi, Y. Recombinant wild-type measles virus containing a single N481Y substitution in its haemagglutinin cannot use receptor CD46 as efficiently as that having the haemagglutinin of the Edmonston laboratory strain. J. Gen. Virol. 2006, 87, 1643-1648. [CrossRef] [PubMed]

5. Tahara, M.; Takeda, M.; Seki, F.; Hashiguchi, T.; Yanagi, Y. Multiple amino acid substitutions in hemagglutinin are necessary for wild-type measles virus to acquire the ability to use receptor CD46 efficiently. J. Virol. 2007, 81, 2564-2572. [CrossRef]

6. Navaratnarajah, C.K.; Vongpunsawad, S.; Oezguen, N.; Stehle, T.; Braun, W.; Hashiguchi, T.; Maenaka, K.; Yanagi, Y.; Cattaneo, R. Dynamic interaction of the measles virus hemagglutinin with its receptor signaling lymphocytic activation molecule (SLAM, CD150). J. Biol. Chem. 2008, 283, 11763-11771. [CrossRef]

7. Kelly, E.; Russell, S.J. History of Oncolytic Viruses: Genesis to Genetic Engineering. Mol. Ther. 2007, 15, 651-659. [CrossRef]

8. Bluming, A.Z.; Ziegler, J.L. Regression of burkitt's lymphoma in association with measles infection. Lancet 1971, 2, $105-106$. [CrossRef]

9. Moss, W.J. Measles. Lancet 2017, 390, 2490-2502. [CrossRef]

10. Di Pietrantonj, C.; Rivetti, A.; Marchione, P.; Debalini, M.G.; Demicheli, V. Vaccines for measles, mumps, rubella, and varicella in children. Cochrane Database Syst. Rev. 2020, 4, CD004407. [CrossRef]

11. Grote, D.; Russell, S.J.; Cornu, T.I.; Cattaneo, R.; Vile, R.; Poland, G.A.; Fielding, A.K. Live attenuated measles virus induces regression of human lymphoma xenografts in immunodeficient mice. Blood 2001, 97, 3746-3754. [CrossRef]

12. Peng, K.W.; Facteau, S.; Wegman, T.; O'Kane, D.; Russell, S.J. Non-invasive in vivo monitoring of trackable viruses expressing soluble marker peptides. Nat. Med. 2002, 8, 527-531. [CrossRef] [PubMed]

13. Peng, K.W.; Donovan, K.A.; Schneider, U.; Cattaneo, R.; Lust, J.A.; Russell, S.J. Oncolytic measles viruses displaying a single-chain antibody against CD38, a myeloma cell marker. Blood 2003, 101, 2557-2562. [CrossRef] [PubMed]

14. Grote, D.; Cattaneo, R.; Fielding, A.K. Neutrophils contribute to the measles virus-induced antitumor effect: Enhancement by granulocyte macrophage colony-stimulating factor expression. Cancer Res. 2003, 63, 6463-6468. [PubMed]

15. Peng, K.W.; TenEyck, C.J.; Galanis, E.; Kalli, K.R.; Hartmann, L.C.; Russell, S.J. Intraperitoneal therapy of ovarian cancer using an engineered measles virus. Cancer Res. 2002, 62, 4656-4662.

16. Phuong, L.K.; Allen, C.; Peng, K.-W.; Giannini, C.; Greiner, S.; TenEyck, C.J.; Mishra, P.; Macura, S.; Russell, S.J.; Galanis, E. Use of a vaccine strain of measles virus genetically engineered to produce carcinoembryonic antigen as a novel therapeutic agent against glioblastoma multiforme. Cancer Res. 2003, 63, 2462-2469.

17. Peng, K.W.; Ahmann, G.J.; Pham, L.; Greipp, P.R.; Cattaneo, R.; Russell, S.J. Systemic therapy of myeloma xenografts by an attenuated measles virus. Blood 2001, 98, 2002-2007. [CrossRef]

18. Mühlebach, M.D. Measles virus in cancer therapy. Curr. Opin. Virol. 2020, 41, 85-97. [CrossRef] 
19. Gauvrit, A.; Brandler, S.; Sapede-Peroz, C.; Boisgerault, N.; Tangy, F.; Gregoire, M. Measles Virus Induces Oncolysis of Mesothelioma Cells and Allows Dendritic Cells to Cross-Prime Tumor-Specific CD8 Response. Cancer Res. 2008, 68, 4882-4892. [CrossRef]

20. Zimmermann, M.; Armeanu, S.; Smirnow, I.; Kupka, S.; Wagner, S.; Wehrmann, M.; Rots, M.G.; Groothuis, G.M.; Weiss, T.S.; Königsrainer, A.; et al. Human precision-cut liver tumor slices as a tumor patient-individual predictive test system for oncolytic measles vaccine viruses. Int. J. Oncol. 2009, 34, 1247-1256.

21. Lv, Y.; Zhou, D.; Hao, X.Q.; Zhu, M.Y.; Zhang, C.D.; Zhou, D.M.; Wang, J.H.; Liu, R.X.; Wang, Y.L.; Gu, W.Z.; et al. A recombinant measles virus vaccine strain rmv-hu191 has oncolytic effect against human gastric cancer by inducing apoptotic cell death requiring integrity of lipid raft microdomains. Cancer Lett. 2019, 460, 108-118. [CrossRef] [PubMed]

22. Ammour, Y.; Ryabaya, O.; Shchetinina, Y.; Prokofeva, E.; Gavrilova, M.; Khochenkov, D.A.; Vorobyev, D.; Faizuloev, E.; Shohin, I.E.; Zverev, V.V.; et al. The Susceptibility of Human Melanoma Cells to Infection with the Leningrad-16 Vaccine Strain of Measles Virus. Viruses 2020, 12, 173. [CrossRef] [PubMed]

23. Ong, H.T.; Timm, M.M.; Greipp, P.R.; Witzig, T.E.; Dispenzieri, A.; Russell, S.J.; Peng, K.-W. Oncolytic measles virus targets high CD46 expression on multiple myeloma cells. Exp. Hematol. 2006, 34, 713-720. [CrossRef] [PubMed]

24. Anderson, B.D.; Nakamura, T.; Russell, S.J.; Peng, K.-W. High CD46 Receptor Density Determines Preferential Killing of Tumor Cells by Oncolytic Measles Virus. Cancer Res. 2004, 64, 4919-4926. [CrossRef]

25. Lok, A.; Descamps, G.; Tessoulin, B.; Chiron, D.; Eveillard, M.; Godon, C.; Le Bris, Y.; Vabret, A.; Bellanger, C.; Maillet, L.; et al. p53 regulates CD46 expression and measles virus infection in myeloma cells. Blood Adv. 2018, 2, 3492-3505. [CrossRef]

26. Noyce, R.S.; Richardson, C.D. Nectin 4 is the epithelial cell receptor for measles virus. Trends Microbiol. 2012, 20, 429-439. [CrossRef]

27. Mühlebach, M.D.; Mateo, M.; Sinn, P.L.; Prüfer, S.; Uhlig, K.M.; Leonard, V.H.J.; Navaratnarajah, C.K.; Frenzke, M.; Wong, X.X.; Sawatsky, B.; et al. Adherens junction protein nectin-4 is the epithelial receptor for measles virus. Nat. Cell Biol. 2011, 480, 530-533. [CrossRef]

28. Awano, M.; Fujiyuki, T.; Shoji, K.; Amagai, Y.; Murakami, Y.; Furukawa, Y.; Sato, H.; Yoneda, M.; Kai, C. Measles virus selectively blind to signaling lymphocyte activity molecule has oncolytic efficacy against nectin-4-expressing pancreatic cancer cells. Cancer Sci. 2016, 107, 1647-1652. [CrossRef]

29. Amagai, Y.; Fujiyuki, T.; Yoneda, M.; Shoji, K.; Furukawa, Y.; Sato, H.; Kai, C. Oncolytic Activity of a Recombinant Measles Virus, Blind to Signaling Lymphocyte Activation Molecule, Against Colorectal Cancer Cells. Sci. Rep. 2016, 6, 24572. [CrossRef]

30. Delpeut, S.; Sisson, G.; Black, K.M.; Richardson, C.D. Measles Virus Enters Breast and Colon Cancer Cell Lines through a PVRL4-Mediated Macropinocytosis Pathway. J. Virol. 2017, 91, e02191-16. [CrossRef]

31. Geekiyanage, H.; Galanis, E. MiR-31 and miR-128 regulates poliovirus receptor-related 4 mediated measles virus infectivity in tumors. Mol. Oncol. 2016, 10, 1387-1403. [CrossRef] [PubMed]

32. Takeda, S.; Kanbayashi, D.; Kurata, T.; Yoshiyama, H.; Komano, J. Enhanced susceptibility ofBlymphoma cells to measles virus byEpstein-Barr virus typeIIIlatency that upregulatesCD150/signaling lymphocytic activation molecule. Cancer Sci. 2014, 105, 211-218. [CrossRef] [PubMed]

33. Noll, M.; Berchtold, S.; Lampe, J.; Malek, N.P.; Bitzer, M.; Lauer, U.M. Primary resistance phenomena to oncolytic measles vaccine viruses. Int. J. Oncol. 2013, 43, 103-112. [CrossRef] [PubMed]

34. Parrula, C.; Fernandez, S.A.; Zimmerman, B.; Lairmore, M.; Niewiesk, S. Measles virotherapy in a mouse model of adult T-cell leukaemia/lymphoma. J. Gen. Virol. 2011, 92, 1458-1466. [CrossRef] [PubMed]

35. Achard, C.; Boisgerault, N.; Delaunay, T.; Roulois, D.; Nedellec, S.; Royer, P.-J.; Pain, M.; Combredet, C.; Mesel-Lemoine, M.; Cellerin, L.; et al. Sensitivity of human pleural mesothelioma to oncolytic measles virus depends on defects of the type I interferon response. Oncotarget 2015, 6, 44892-44904. [CrossRef]

36. Allagui, F.; Achard, C.; Panterne, C.; Combredet, C.; Labarrière, N.; Dréno, B.; Elgaaied, A.B.; Pouliquen, D.; Tangy, F.; Fonteneau, J.F.; et al. Modulation of the type i interferon response defines the sensitivity of human melanoma cells to oncolytic measles virus. Curr. Gene Ther. 2017, 16, 419-428. [CrossRef]

37. Berchtold, S.; Lampe, J.; Weiland, T.; Smirnow, I.; Schleicher, S.; Handgretinger, R.; Kopp, H.-G.; Reiser, J.; Stubenrauch, F.; Mayer, N.; et al. Innate Immune Defense Defines Susceptibility of Sarcoma Cells to Measles Vaccine Virus-Based Oncolysis. J. Virol. 2013, 87, 3484-3501. [CrossRef]

38. Aref, S.; Castleton, A.Z.; Bailey, K.; Burt, R.; Dey, A.; Leongamornlert, D.; Mitchell, R.J.; Okasha, D.; Fielding, A.K. Type 1 Interferon Responses Underlie Tumor-Selective Replication of Oncolytic Measles Virus. Mol. Ther. 2020, 28, 1043-1055. [CrossRef]

39. Kurokawa, C.; Iankov, I.D.; Anderson, S.K.; Aderca, I.; Leontovich, A.A.; Maurer, M.J.; Oberg, A.L.; Schroeder, M.A.; Giannini, C.; Greiner, S.M.; et al. Constitutive Interferon Pathway Activation in Tumors as an Efficacy Determinant Following Oncolytic Virotherapy. J. Natl. Cancer Inst. 2018, 110, 1123-1132. [CrossRef]

40. Kurokawa, C.; Iankov, I.D.; Galanis, E. A key anti-viral protein, RSAD2/VIPERIN, restricts the release of measles virus from infected cells. Virus Res. 2019, 263, 145-150. [CrossRef]

41. Boisgerault, N.; Guillerme, J.-B.; Pouliquen, D.; Mesel-Lemoine, M.; Achard, C.; Combredet, C.; Fonteneau, J.-F.; Tangy, F.; Gregoire, M. Natural Oncolytic Activity of Live-Attenuated Measles Virus against Human Lung and Colorectal Adenocarcinomas. BioMed. Res. Int. 2013, 2013, 1-11. [CrossRef] [PubMed]

42. Wang, B.; Yan, X.; Guo, Q.; Li, Y.; Zhang, H.; Xie, J.S.; Meng, X. Deficiency of caspase 3 in tumor xenograft impairs therapeutic effect of measles virus Edmoston strain. Oncotarget 2015, 6, 16019-16030. [CrossRef] [PubMed] 
43. Patel, B.; Dey, A.; Ghorani, E.; Kumar, S.; Malam, Y.; Rai, L.; Steele, A.J.; Thomson, J.; Wickremasinghe, R.G.; Zhang, Y.; et al. Differential Cytopathology and Kinetics of Measles Oncolysis in Two Primary B-cell Malignancies Provides Mechanistic Insights. Mol. Ther. 2011, 19, 1034-1040. [CrossRef] [PubMed]

44. Jacobson, B.A.; Sadiq, A.A.; Tang, S.; Jay-Dixon, J.; Patel, M.R.; Drees, J.; Sorenson, B.S.; Russell, S.J.; Kratzke, R.A. Cap-dependent translational control of oncolytic measles virus infection in malignant mesothelioma. Oncotarget 2017, 8, 63096-63109. [CrossRef]

45. Bossow, S.; Grossardt, C.; Temme, A.; Leber, M.F.; Sawall, S.; Rieber, E.P.; Cattaneo, R.; Von Kalle, C.; Ungerechts, G. Armed and targeted measles virus for chemovirotherapy of pancreatic cancer. Cancer Gene Ther. 2011, 18, 598-608. [CrossRef]

46. Weiland, T.; Lampe, J.; Essmann, F.; Venturelli, S.; Berger, A.; Bossow, S.; Berchtold, S.; Schulze-Osthoff, K.; Lauer, U.M.; Bitzer, M. Enhanced killing of therapy-induced senescent tumor cells by oncolytic measles vaccine viruses. Int. J. Cancer 2013, 134, 235-243. [CrossRef]

47. Leber, M.F.; Neault, S.; Jirovec, E.; Barkley, R.; Said, A.; Bell, J.C.; Ungerechts, G. Engineering and combining oncolytic measles virus for cancer therapy. Cytokine Growth Factor Rev. 2020. [CrossRef]

48. Liu, C.; Sarkaria, J.N.; Petell, C.A.; Paraskevakou, G.; Zollman, P.J.; Schroeder, M.; Carlson, B.; Decker, P.A.; Wu, W.; James, C.D.; et al. Combination of measles virus virotherapy and radiation therapy has synergistic activity in the treatment of glioblastoma multiforme. Clin. Cancer Res. 2007, 13, 7155-7165. [CrossRef]

49. Lal, G.; Rajala, M.S. Combination of Oncolytic Measles Virus Armed With BNiP3, a Pro-apoptotic Gene and Paclitaxel Induces Breast Cancer Cell Death. Front. Oncol. 2018, 8, 676. [CrossRef]

50. Tai, C.J.; Liu, C.H.; Pan, Y.C.; Wong, S.H.; Tai, C.J.; Richardson, C.D.; Lin, L.T. Chemovirotherapeutic Treatment Using Camptothecin Enhances Oncolytic Measles Virus-Mediated Killing of Breast Cancer Cells. Sci. Rep. 2019, 9, 6767. [CrossRef]

51. May, V.; Berchtold, S.; Berger, A.; Venturelli, S.; Burkard, M.; Leischner, C.; Malek, N.P.; Lauer, U.M. Chemovirotherapy for pancreatic cancer: Gemcitabine plus oncolytic measles vaccine virus. Oncol. Lett. 2019, 18, 5534-5542. [CrossRef] [PubMed]

52. Toan, N.L.; Hang, N.T.; Luu, N.K.; Van Mao, C.; Van Ba, N.; Xuan, N.T.; Cam, T.D.; Yamamoto, N.; Van Tong, H.; Son, H.A. Combination of Vaccine Strain Measles Virus and Nimotuzumab in the Treatment of Laryngeal Cancer. Anticancer Res. 2019, 39, 3727-3737. [CrossRef] [PubMed]

53. Zou, J.; Guo, Y.; Guettouche, T.; Smith, D.F.; Voellmy, R. Repression of heat shock transcription factor HSF1 activation by HSP90 (HSP90 complex) that forms a stress-sensitive complex with HSF1. Cell 1998, 94, 471-480. [CrossRef]

54. Muchowski, P.J.; Wacker, J.L. Modulation of neurodegeneration by molecular chaperones. Nat. Rev. Neurosci. 2005, 6, 11-22. [CrossRef] [PubMed]

55. Liu, C.; Erlichman, C.; McDonald, C.J.; Ingle, J.N.; Zollman, P.; Iankov, I.; Russell, S.J.; Galanis, E. Heat shock protein inhibitors increase the efficacy of measles virotherapy. Gene Ther. 2008, 15, 1024-1034. [CrossRef] [PubMed]

56. Stewart, C.E.; Randall, R.E.; Adamson, C.S. Inhibitors of the interferon response enhance virus replication in vitro. PLoS ONE 2014, 9, e112014. [CrossRef]

57. Ruf, B.; Berchtold, S.; Venturelli, S.; Burkard, M.; Smirnow, I.; Prenzel, T.; Henning, S.W.; Lauer, U.M. Combination of the oral histone deacetylase inhibitor resminostat with oncolytic measles vaccine virus as a new option for epi-virotherapeutic treatment of hepatocellular carcinoma. Mol. Ther. Oncolytics 2015, 2, 15019. [CrossRef]

58. Ellerhoff, T.P.; Berchtold, S.; Venturelli, S.; Burkard, M.; Smirnow, I.; Wulff, T.; Lauer, U.M. Novel epi-virotherapeutic treatment of pancreatic cancer combining the oral histone deacetylase inhibitor resminostat with oncolytic measles vaccine virus. Int. J. Oncol. 2016, 49, 1931-1944. [CrossRef]

59. Opyrchal, M.; Allen, C.; Msaouel, P.; Iankov, I.; Galanis, E. Inhibition of Rho-associated coiled-coil-forming kinase increases efficacy of measles virotherapy. Cancer Gene Ther. 2013, 20, 630-637. [CrossRef]

60. Li, C.; Meng, G.; Su, L.; Chen, A.; Xia, M.; Xu, C.; Yu, D.; Jiang, A.; Wei, J. Dichloroacetate blocks aerobic glycolytic adaptation to attenuated measles virus and promotes viral replication leading to enhanced oncolysis in glioblastoma. Oncotarget 2015, 6, 1544-1555. [CrossRef]

61. Xia, M.; Gonzalez, P.; Li, C.; Meng, G.; Jiang, A.; Wang, H.; Gao, Q.; Debatin, K.M.; Beltinger, C.; Wei, J. Mitophagy enhances oncolytic measles virus replication by mitigating DDX58/RIG-I-like receptor signaling. J. Virol. 2014, 88, 5152-5164. [CrossRef] [PubMed]

62. Son, H.A.; Zhang, L.; Cuong, B.K.; Van Tong, H.; Cuong, L.D.; Hang, N.T.; Nhung, H.T.M.; Yamamoto, N.; Toan, N.L. Combination of Vaccine-Strain Measles and Mumps Viruses Enhances Oncolytic Activity against Human Solid Malignancies. Cancer Invest. 2018, 36, 106-117. [CrossRef] [PubMed]

63. Radecke, F.; Spielhofer, P.; Schneider, H.; Kaelin, K.; Huber, M.; Dötsch, C.; Christiansen, G.; Billeter, M.A. Rescue of measles viruses from cloned DNA. Embo J. 1995, 14, 5773-5784. [CrossRef] [PubMed]

64. Pfaller, C.K.; Cattaneo, R.; Schnell, M.J. Reverse genetics of Mononegavirales: How they work, new vaccines, and new cancer therapeutics. Virology 2015, 479-480, 331-344. [CrossRef] [PubMed]

65. Aref, S.; Bailey, K.; Fielding, A. Measles to the Rescue: A Review of Oncolytic Measles Virus. Viruses 2016, 8, 294. [CrossRef] [PubMed]

66. Dingli, D.; Peng, K.W.; Harvey, M.E.; Greipp, P.R.; O'Connor, M.K.; Cattaneo, R.; Morris, J.C.; Russell, S.J. Image-guided radiovirotherapy for multiple myeloma using a recombinant measles virus expressing the thyroidal sodium iodide symporter. Blood 2004, 103, 1641-1646. [CrossRef] 
67. Penheiter, A.R.; Griesmann, G.E.; Federspiel, M.J.; Dingli, D.; Russell, S.J.; Carlson, S.K. Pinhole micro-SPECT/CT for noninvasive monitoring and quantitation of oncolytic virus dispersion and percent infection in solid tumors. Gene Ther. 2012, 19, $279-287$. [CrossRef]

68. Penheiter, A.R.; Dingli, D.; Bender, C.E.; Russell, S.J.; Carlson, S.K. Monitoring the initial delivery of an oncolytic measles virus encoding the human sodium iodide symporter to solid tumors using contrast-enhanced computed tomography. J. Gene Med. 2012, 14, 590-597. [CrossRef]

69. Kemler, I.; Ennis, M.K.; Neuhauser, C.M.; Dingli, D. In Vivo Imaging of Oncolytic Measles Virus Propagation with Single-Cell Resolution. Mol. Ther. Oncolytics 2019, 12, 68-78. [CrossRef]

70. Dingli, D.; Cascino, M.D.; Josić, K.; Russell, S.J.; Bajzer, Z. Mathematical modeling of cancer radiovirotherapy. Math Biosci. 2006, 199, 55-78. [CrossRef]

71. Bajzer, Z.; Carr, T.; Josić, K.; Russell, S.J.; Dingli, D. Modeling of cancer virotherapy with recombinant measles viruses. J Theor Biol 2008, 252, 109-122. [CrossRef] [PubMed]

72. Berg, D.R.; Offord, C.P.; Kemler, I.; Ennis, M.K.; Chang, L.; Paulik, G.; Bajzer, Z.; Neuhauser, C.; Dingli, D. In vitro and in silico multidimensional modeling of oncolytic tumor virotherapy dynamics. PLoS Comput. Biol. 2019, 15, e1006773. [CrossRef]

73. Biesecker, M.; Kimn, J.H.; Lu, H.; Dingli, D.; Bajzer, Z. Optimization of virotherapy for cancer. Bull Math Biol 2010, 72, 469-489. [CrossRef] [PubMed]

74. Galanis, E.; Hartmann, L.C.; Cliby, W.A.; Long, H.J.; Peethambaram, P.P.; Barrette, B.A.; Kaur, J.S.; Haluska, P.J., Jr.; Aderca, I.; Zollman, P.J.; et al. Phase I trial of intraperitoneal administration of an oncolytic measles virus strain engineered to express carcinoembryonic antigen for recurrent ovarian cancer. Cancer Res. 2010, 70, 875-882. [CrossRef] [PubMed]

75. Dispenzieri, A.; Tong, C.; LaPlant, B.; Lacy, M.Q.; Laumann, K.; Dingli, D.; Zhou, Y.; Federspiel, M.J.; Gertz, M.A.; Hayman, S.; et al. Phase I trial of systemic administration of Edmonston strain of measles virus genetically engineered to express the sodium iodide symporter in patients with recurrent or refractory multiple myeloma. Leukemia 2017, 31, 2791-2798. [CrossRef] [PubMed]

76. Nakamura, T.; Peng, K.W.; Harvey, M.; Greiner, S.; Lorimer, I.A.; James, C.D.; Russell, S.J. Rescue and propagation of fully retargeted oncolytic measles viruses. Nat. Biotechnol. 2005, 23, 209-214. [CrossRef] [PubMed]

77. Bucheit, A.D.; Kumar, S.; Grote, D.M.; Lin, Y.; von Messling, V.; Cattaneo, R.B.; Fielding, A.K. An oncolytic measles virus engineered to enter cells through the CD20 antigen. Mol. Ther. 2003, 7, 62-72. [CrossRef]

78. Hasegawa, K.; Nakamura, T.; Harvey, M.; Ikeda, Y.; Oberg, A.; Figini, M.; Canevari, S.; Hartmann, L.C.; Peng, K.W. The use of a tropism-modified measles virus in folate receptor-targeted virotherapy of ovarian cancer. Clin. Cancer Res. 2006, 12, 6170-6178. [CrossRef] [PubMed]

79. Allen, C.; Vongpunsawad, S.; Nakamura, T.; James, C.D.; Schroeder, M.; Cattaneo, R.; Giannini, C.; Krempski, J.; Peng, K.W.; Goble, J.M.; et al. Retargeted oncolytic measles strains entering via the EGFRvIII receptor maintain significant antitumor activity against gliomas with increased tumor specificity. Cancer Res. 2006, 66, 11840-11850. [CrossRef]

80. Allen, C.; Paraskevakou, G.; Iankov, I.; Giannini, C.; Schroeder, M.; Sarkaria, J.; Puri, R.K.; Russell, S.J.; Galanis, E. Interleukin-13 Displaying Retargeted Oncolytic Measles Virus Strains Have Significant Activity Against Gliomas With Improved Specificity. Mol. Ther. 2008, 16, 1556-1564. [CrossRef]

81. Jing, Y.; Tong, C.; Zhang, J.; Nakamura, T.; Iankov, I.; Russell, S.J.; Merchan, J.R. Tumor and vascular targeting of a novel oncolytic measles virus retargeted against the urokinase receptor. Cancer Res. 2009, 69, 1459-1468. [CrossRef] [PubMed]

82. Ong, H.T.; Trejo, T.R.; Pham, L.D.; Oberg, A.L.; Russell, S.J.; Peng, K.W. Intravascularly administered RGD-displaying measles viruses bind to and infect neovessel endothelial cells in vivo. Mol. Ther. 2009, 17, 1012-1021. [CrossRef] [PubMed]

83. Friedrich, K.; Hanauer, J.R.; Prüfer, S.; Münch, R.C.; Völker, I.; Filippis, C.; Jost, C.; Hanschmann, K.M.; Cattaneo, R.; Peng, K.W.; et al. DARPin-targeting of measles virus: Unique bispecificity, effective oncolysis, and enhanced safety. Mol. Ther. 2013, 21, 849-859. [CrossRef]

84. Lal, S.; Raffel, C. Using Cystine Knot Proteins as a Novel Approach to Retarget Oncolytic Measles Virus. Mol. Ther. Oncolytics 2017, 7, 57-66. [CrossRef]

85. Bach, P.; Abel, T.; Hoffmann, C.; Gal, Z.; Braun, G.; Voelker, I.; Ball, C.R.; Johnston, I.C.; Lauer, U.M.; Herold-Mende, C.; et al. Specific elimination of CD133+ tumor cells with targeted oncolytic measles virus. Cancer Res. 2013, 73, 865-874. [CrossRef] [PubMed]

86. Jing, Y.; Chavez, V.; Ban, Y.; Acquavella, N.; El-Ashry, D.; Pronin, A.; Chen, X.; Merchan, J.R. Molecular Effects of Stromal-Selective Targeting by uPAR-Retargeted Oncolytic Virus in Breast Cancer. Mol. Cancer Res. 2017, 15, 1410-1420. [CrossRef] [PubMed]

87. Springfeld, C.; von Messling, V.; Frenzke, M.; Ungerechts, G.; Buchholz, C.J.; Cattaneo, R. Oncolytic efficacy and enhanced safety of measles virus activated by tumor-secreted matrix metalloproteinases. Cancer Res. 2006, 66, 7694-7700. [CrossRef]

88. Mühlebach, M.D.; Schaser, T.; Zimmermann, M.; Armeanu, S.; Hanschmann, K.M.; Cattaneo, R.; Bitzer, M.; Lauer, U.M.; Cichutek, K.; Buchholz, C.J. Liver cancer protease activity profiles support therapeutic options with matrix metalloproteinase-activatable oncolytic measles virus. Cancer Res. 2010, 70, 7620-7629. [CrossRef]

89. Leber, M.F.; Bossow, S.; Leonard, V.H.; Zaoui, K.; Grossardt, C.; Frenzke, M.; Miest, T.; Sawall, S.; Cattaneo, R.; von Kalle, C.; et al. MicroRNA-sensitive oncolytic measles viruses for cancer-specific vector tropism. Mol. Ther. 2011, 19, 1097-1106. [CrossRef]

90. Ketzer, P.; Kaufmann, J.K.; Engelhardt, S.; Bossow, S.; von Kalle, C.; Hartig, J.S.; Ungerechts, G.; Nettelbeck, D.M. Artificial riboswitches for gene expression and replication control of DNA and RNA viruses. Proc. Natl. Acad. Sci. USA 2014, 111, E554-E562. [CrossRef] 
91. Tahara, M.; Takishima, Y.; Miyamoto, S.; Nakatsu, Y.; Someya, K.; Sato, M.; Tani, K.; Takeda, M. Photocontrollable mononegaviruses. Proc. Natl. Acad. Sci. USA 2019, 116, 11587-11589. [CrossRef]

92. Ungerechts, G.; Springfeld, C.; Frenzke, M.E.; Lampe, J.; Johnston, P.B.; Parker, W.B.; Sorscher, E.J.; Cattaneo, R. Lymphoma chemovirotherapy: CD20-targeted and convertase-armed measles virus can synergize with fludarabine. Cancer Res. 2007, 67, 10939-10947. [CrossRef] [PubMed]

93. Ungerechts, G.; Springfeld, C.; Frenzke, M.E.; Lampe, J.; Parker, W.B.; Sorscher, E.J.; Cattaneo, R. An immunocompetent murine model for oncolysis with an armed and targeted measles virus. Mol. Ther. 2007, 15, 1991-1997. [CrossRef] [PubMed]

94. Lange, S.; Lampe, J.; Bossow, S.; Zimmermann, M.; Neubert, W.; Bitzer, M.; Lauer, U.M. A novel armed oncolytic measles vaccine virus for the treatment of cholangiocarcinoma. Hum. Gene Ther. 2013, 24, 554-564. [CrossRef] [PubMed]

95. Hartkopf, A.D.; Bossow, S.; Lampe, J.; Zimmermann, M.; Taran, F.A.; Wallwiener, D.; Fehm, T.; Bitzer, M.; Lauer, U.M. Enhanced killing of ovarian carcinoma using oncolytic measles vaccine virus armed with a yeast cytosine deaminase and uracil phosphoribosyltransferase. Gynecol. Oncol. 2013, 130, 362-368. [CrossRef]

96. Kaufmann, J.K.; Bossow, S.; Grossardt, C.; Sawall, S.; Kupsch, J.; Erbs, P.; Hassel, J.C.; von Kalle, C.; Enk, A.H.; Nettelbeck, D.M.; et al. Chemovirotherapy of malignant melanoma with a targeted and armed oncolytic measles virus. J. Invest. Dermatol. 2013, 133, 1034-1042. [CrossRef]

97. Lampe, J.; Bossow, S.; Weiland, T.; Smirnow, I.; Lehmann, R.; Neubert, W.; Bitzer, M.; Lauer, U.M. An armed oncolytic measles vaccine virus eliminates human hepatoma cells independently of apoptosis. Gene Ther. 2013, 20, 1033-1041. [CrossRef]

98. Hutzen, B.; Bid, H.K.; Houghton, P.J.; Pierson, C.R.; Powell, K.; Bratasz, A.; Raffel, C.; Studebaker, A.W. Treatment of medulloblastoma with oncolytic measles viruses expressing the angiogenesis inhibitors endostatin and angiostatin. BMC Cancer 2014, 14, 206. [CrossRef]

99. Pidelaserra-Martí, G.; Engeland, C.E. Mechanisms of measles virus oncolytic immunotherapy. Cytokine Growth Factor Rev. 2020. [CrossRef]

100. Donnelly, O.G.; Errington-Mais, F.; Steele, L.; Hadac, E.; Jennings, V.; Scott, K.; Peach, H.; Phillips, R.M.; Bond, J.; Pandha, H.; et al. Measles virus causes immunogenic cell death in human melanoma. Gene Ther. 2013, 20, 7-15. [CrossRef]

101. Rajaraman, S.; Canjuga, D.; Ghosh, M.; Codrea, M.C.; Sieger, R.; Wedekink, F.; Tatagiba, M.; Koch, M.; Lauer, U.M.; Nahnsen, S.; et al. Measles Virus-Based Treatments Trigger a Pro-inflammatory Cascade and a Distinctive Immunopeptidome in Glioblastoma. Mol. Ther. Oncolytics 2019, 12, 147-161. [CrossRef]

102. Guillerme, J.B.; Boisgerault, N.; Roulois, D.; Ménager, J.; Combredet, C.; Tangy, F.; Fonteneau, J.F.; Gregoire, M. Measles virus vaccine-infected tumor cells induce tumor antigen cross-presentation by human plasmacytoid dendritic cells. Clin. Cancer Res. 2013, 19, 1147-1158. [CrossRef]

103. Achard, C.; Guillerme, J.B.; Bruni, D.; Boisgerault, N.; Combredet, C.; Tangy, F.; Jouvenet, N.; Grégoire, M.; Fonteneau, J.F. Oncolytic measles virus induces tumor necrosis factor-related apoptosis-inducing ligand (TRAIL)-mediated cytotoxicity by human myeloid and plasmacytoid dendritic cells. Oncoimmunology 2017, 6, e1261240. [CrossRef]

104. Tan, D.Q.; Zhang, L.; Ohba, K.; Ye, M.; Ichiyama, K.; Yamamoto, N. Macrophage response to oncolytic paramyxoviruses potentiates virus-mediated tumor cell killing. Eur. J. Immunol. 2016, 46, 919-928. [CrossRef]

105. Zhang, Y.; Patel, B.; Dey, A.; Ghorani, E.; Rai, L.; Elham, M.; Castleton, A.Z.; Fielding, A.K. Attenuated, oncolytic, but not wild-type measles virus infection has pleiotropic effects on human neutrophil function. J. Immunol. 2012, 188, 1002-1010. [CrossRef]

106. Dey, A.; Zhang, Y.; Castleton, A.Z.; Bailey, K.; Beaton, B.; Patel, B.; Fielding, A.K. The Role of Neutrophils in Measles Virusmediated Oncolysis Differs Between B-cell Malignancies and Is Not Always Enhanced by GCSF. Mol. Ther. 2016, 24, 184-192. [CrossRef]

107. Li, H.; Peng, K.W.; Dingli, D.; Kratzke, R.A.; Russell, S.J. Oncolytic measles viruses encoding interferon beta and the thyroidal sodium iodide symporter gene for mesothelioma virotherapy. Cancer Gene Ther. 2010, 17, 550-558. [CrossRef]

108. Iankov, I.D.; Allen, C.; Federspiel, M.J.; Myers, R.M.; Peng, K.W.; Ingle, J.N.; Russell, S.J.; Galanis, E. Expression of immunomodulatory neutrophil-activating protein of Helicobacter pylori enhances the antitumor activity of oncolytic measles virus. Mol. Ther. 2012, 20, 1139-1147. [CrossRef]

109. Grossardt, C.; Engeland, C.E.; Bossow, S.; Halama, N.; Zaoui, K.; Leber, M.F.; Springfeld, C.; Jaeger, D.; von Kalle, C.; Ungerechts, G. Granulocyte-macrophage colony-stimulating factor-armed oncolytic measles virus is an effective therapeutic cancer vaccine. Hum. Gene Ther. 2013, 24, 644-654. [CrossRef]

110. Engeland, C.E.; Grossardt, C.; Veinalde, R.; Bossow, S.; Lutz, D.; Kaufmann, J.K.; Shevchenko, I.; Umansky, V.; Nettelbeck, D.M.; Weichert, W.; et al. CTLA-4 and PD-L1 checkpoint blockade enhances oncolytic measles virus therapy. Mol. Ther. 2014, 22, 1949-1959. [CrossRef]

111. Veinalde, R.; Grossardt, C.; Hartmann, L.; Bourgeois-Daigneault, M.C.; Bell, J.C.; Jäger, D.; von Kalle, C.; Ungerechts, G.; Engeland, C.E. Oncolytic measles virus encoding interleukin-12 mediates potent antitumor effects through T cell activation. Oncoimmunology 2017, 6, e1285992. [CrossRef] [PubMed]

112. Backhaus, P.S.; Veinalde, R.; Hartmann, L.; Dunder, J.E.; Jeworowski, L.M.; Albert, J.; Hoyler, B.; Poth, T.; Jäger, D.; Ungerechts, G.; et al. Immunological Effects and Viral Gene Expression Determine the Efficacy of Oncolytic Measles Vaccines Encoding IL-12 or IL-15 Agonists. Viruses 2019, 11, 914. [CrossRef] [PubMed] 
113. Speck, T.; Heidbuechel, J.P.W.; Veinalde, R.; Jaeger, D.; von Kalle, C.; Ball, C.R.; Ungerechts, G.; Engeland, C.E. Targeted BiTE Expression by an Oncolytic Vector Augments Therapeutic Efficacy Against Solid Tumors. Clin. Cancer Res. 2018, 24, $2128-2137$. [CrossRef] [PubMed]

114. Hutzler, S.; Erbar, S.; Jabulowsky, R.A.; Hanauer, J.R.H.; Schnotz, J.H.; Beissert, T.; Bodmer, B.S.; Eberle, R.; Boller, K.; Klamp, T.; et al. Antigen-specific oncolytic MV-based tumor vaccines through presentation of selected tumor-associated antigens on infected cells or virus-like particles. Sci. Rep. 2017, 7, 16892. [CrossRef] [PubMed]

115. Busch, E.; Kubon, K.D.; Mayer, J.K.M.; Pidelaserra-Martí, G.; Albert, J.; Hoyler, B.; Heidbuechel, J.P.W.; Stephenson, K.B.; Lichty, B.D.; Osen, W.; et al. Measles Vaccines Designed for Enhanced CD8(+) T Cell Activation. Viruses 2020, 12, 242. [CrossRef]

116. Hardcastle, J.; Mills, L.; Malo, C.S.; Jin, F.; Kurokawa, C.; Geekiyanage, H.; Schroeder, M.; Sarkaria, J.; Johnson, A.J.; Galanis, E. Immunovirotherapy with measles virus strains in combination with anti-PD-1 antibody blockade enhances antitumor activity in glioblastoma treatment. Neuro Oncol. 2017, 19, 493-502. [CrossRef]

117. Mühlebach, M.D. Vaccine platform recombinant measles virus. Virus Genes 2017, 53, 733-740. [CrossRef]

118. Hörner, C.; Schürmann, C.; Auste, A.; Ebenig, A.; Muraleedharan, S.; Herrmann, M.; Schnierle, B.; Mühlebach, M.D. A Highly Immunogenic Measles Virus-based Th1-biased COVID-19 Vaccine. bioRxiv 2020.

119. Klose, C.; Berchtold, S.; Schmidt, M.; Beil, J.; Smirnow, I.; Venturelli, S.; Burkard, M.; Handgretinger, R.; Lauer, U.M. Biological treatment of pediatric sarcomas by combined virotherapy and NK cell therapy. BMC Cancer 2019, 19, 1172. [CrossRef]

120. Chen, A.; Zhang, Y.; Meng, G.; Jiang, D.; Zhang, H.; Zheng, M.; Xia, M.; Jiang, A.; Wu, J.; Beltinger, C.; et al. Oncolytic measles virus enhances antitumour responses of adoptive CD8(+)NKG2D(+) cells in hepatocellular carcinoma treatment. Sci. Rep. 2017, 7, 5170. [CrossRef]

121. Heinzerling, L.; Künzi, V.; Oberholzer, P.A.; Kündig, T.; Naim, H.; Dummer, R. Oncolytic measles virus in cutaneous T-cell lymphomas mounts antitumor immune responses in vivo and targets interferon-resistant tumor cells. Blood 2005, 106, 2287-2294. [CrossRef] [PubMed]

122. Galanis, E.; Atherton, P.J.; Maurer, M.J.; Knutson, K.L.; Dowdy, S.C.; Cliby, W.A.; Haluska, P., Jr.; Long, H.J.; Oberg, A.; Aderca, I.; et al. Oncolytic measles virus expressing the sodium iodide symporter to treat drug-resistant ovarian cancer. Cancer Res. 2015, 75, 22-30. [CrossRef] [PubMed]

123. Packiriswamy, N.; Upreti, D.; Zhou, Y.; Khan, R.; Miller, A.; Diaz, R.M.; Rooney, C.M.; Dispenzieri, A.; Peng, K.W.; Russell, S.J. Oncolytic measles virus therapy enhances tumor antigen-specific T-cell responses in patients with multiple myeloma. Leukemia 2020. [CrossRef]

124. Dietz, L.; Engeland, C.E. Immunomodulation in Oncolytic Measles Virotherapy. Methods Mol. Biol. 2020, 2058, 111-126. [CrossRef]

125. Haralambieva, I.; Iankov, I.; Hasegawa, K.; Harvey, M.; Russell, S.J.; Peng, K.W. Engineering oncolytic measles virus to circumvent the intracellular innate immune response. Mol. Ther. 2007, 15, 588-597. [CrossRef]

126. Meng, X.; Nakamura, T.; Okazaki, T.; Inoue, H.; Takahashi, A.; Miyamoto, S.; Sakaguchi, G.; Eto, M.; Naito, S.; Takeda, M.; et al. Enhanced antitumor effects of an engineered measles virus Edmonston strain expressing the wild-type N, P, L genes on human renal cell carcinoma. Mol. Ther. 2010, 18, 544-551. [CrossRef]

127. Dyer, A.; Baugh, R.; Chia, S.L.; Frost, S.; Iris; Jacobus, E.J.; Khalique, H.; Pokrovska, T.D.; Scott, E.M.; Taverner, W.K.; et al. Turning cold tumours hot: Oncolytic virotherapy gets up close and personal with other therapeutics at the 11th Oncolytic Virus Conference. Cancer Gene Ther. 2019, 26, 59-73. [CrossRef]

128. Miest, T.S.; Yaiw, K.C.; Frenzke, M.; Lampe, J.; Hudacek, A.W.; Springfeld, C.; von Messling, V.; Ungerechts, G.; Cattaneo, R. Envelope-chimeric entry-targeted measles virus escapes neutralization and achieves oncolysis. Mol. Ther. 2011, 19, 1813-1820. [CrossRef]

129. Iankov, I.D.; Blechacz, B.; Liu, C.; Schmeckpeper, J.D.; Tarara, J.E.; Federspiel, M.J.; Caplice, N.; Russell, S.J. Infected cell carriers: A new strategy for systemic delivery of oncolytic measles viruses in cancer virotherapy. Mol. Ther. 2007, 15, 114-122. [CrossRef]

130. Ong, H.T.; Hasegawa, K.; Dietz, A.B.; Russell, S.J.; Peng, K.W. Evaluation of T cells as carriers for systemic measles virotherapy in the presence of antiviral antibodies. Gene Ther. 2007, 14, 324-333. [CrossRef]

131. Liu, C.; Suksanpaisan, L.; Chen, Y.W.; Russell, S.J.; Peng, K.W. Enhancing cytokine-induced killer cell therapy of multiple myeloma. Exp. Hematol. 2013, 41, 508-517. [CrossRef] [PubMed]

132. Mader, E.K.; Maeyama, Y.; Lin, Y.; Butler, G.W.; Russell, H.M.; Galanis, E.; Russell, S.J.; Dietz, A.B.; Peng, K.W. Mesenchymal stem cell carriers protect oncolytic measles viruses from antibody neutralization in an orthotopic ovarian cancer therapy model. Clin. Cancer Res. 2009, 15, 7246-7255. [CrossRef]

133. Castleton, A.; Dey, A.; Beaton, B.; Patel, B.; Aucher, A.; Davis, D.M.; Fielding, A.K. Human mesenchymal stromal cells deliver systemic oncolytic measles virus to treat acute lymphoblastic leukemia in the presence of humoral immunity. Blood 2014, 123, 1327-1335. [CrossRef] [PubMed]

134. Liu, C.; Russell, S.J.; Peng, K.W. Systemic therapy of disseminated myeloma in passively immunized mice using measles virus-infected cell carriers. Mol. Ther. 2010, 18, 1155-1164. [CrossRef] [PubMed]

135. Liu, Y.P.; Tong, C.; Dispenzieri, A.; Federspiel, M.J.; Russell, S.J.; Peng, K.W. Polyinosinic acid decreases sequestration and improves systemic therapy of measles virus. Cancer Gene Ther. 2012, 19, 202-211. [CrossRef] [PubMed]

136. Xia, M.; Luo, D.; Dong, J.; Zheng, M.; Meng, G.; Wu, J.; Wei, J. Graphene oxide arms oncolytic measles virus for improved effectiveness of cancer therapy. J. Exp. Clin. Cancer Res. 2019, 38, 408. [CrossRef] 
137. Nosaki, K.; Hamada, K.; Takashima, Y.; Sagara, M.; Matsumura, Y.; Miyamoto, S.; Hijikata, Y.; Okazaki, T.; Nakanishi, Y.; Tani, K. A novel, polymer-coated oncolytic measles virus overcomes immune suppression and induces robust antitumor activity. Mol. Ther. Oncolytics 2016, 3, 16022. [CrossRef]

138. Xu, C.; Goß, A.V.; Dorneburg, C.; Debatin, K.M.; Wei, J.; Beltinger, C. Proof-of-principle that a decoy virus protects oncolytic measles virus against neutralizing antibodies. Oncolytic. Virother. 2018, 7, 37-41. [CrossRef]

139. Peng, K.W.; Myers, R.; Greenslade, A.; Mader, E.; Greiner, S.; Federspiel, M.J.; Dispenzieri, A.; Russell, S.J. Using clinically approved cyclophosphamide regimens to control the humoral immune response to oncolytic viruses. Gene Ther. 2013, 20, 255-261. [CrossRef]

140. Yaiw, K.C.; Miest, T.S.; Frenzke, M.; Timm, M.; Johnston, P.B.; Cattaneo, R. CD20-targeted measles virus shows high oncolytic specificity in clinical samples from lymphoma patients independent of prior rituximab therapy. Gene Ther. 2011, 18, 313-317. [CrossRef]

141. Allen, C.; Opyrchal, M.; Aderca, I.; Schroeder, M.A.; Sarkaria, J.N.; Domingo, E.; Federspiel, M.J.; Galanis, E. Oncolytic measles virus strains have significant antitumor activity against glioma stem cells. Gene Ther. 2013, 20, 444-449. [CrossRef] [PubMed]

142. Iankov, I.D.; Msaouel, P.; Allen, C.; Federspiel, M.J.; Bulur, P.A.; Dietz, A.B.; Gastineau, D.; Ikeda, Y.; Ingle, J.N.; Russell, S.J.; et al. Demonstration of anti-tumor activity of oncolytic measles virus strains in a malignant pleural effusion breast cancer model. Breast Cancer Res. Treat. 2010, 122, 745-754. [CrossRef] [PubMed]

143. Peng, K.W.; Hadac, E.M.; Anderson, B.D.; Myers, R.; Harvey, M.; Greiner, S.M.; Soeffker, D.; Federspiel, M.J.; Russell, S.J. Pharmacokinetics of oncolytic measles virotherapy: Eventual equilibrium between virus and tumor in an ovarian cancer xenograft model. Cancer Gene Ther. 2006, 13, 732-738. [CrossRef]

144. Myers, R.M.; Greiner, S.M.; Harvey, M.E.; Griesmann, G.; Kuffel, M.J.; Buhrow, S.A.; Reid, J.M.; Federspiel, M.; Ames, M.M.; Dingli, D.; et al. Preclinical pharmacology and toxicology of intravenous MV-NIS, an oncolytic measles virus administered with or without cyclophosphamide. Clin. Pharmacol. Ther. 2007, 82, 700-710. [CrossRef] [PubMed]

145. Myers, R.; Harvey, M.; Kaufmann, T.J.; Greiner, S.M.; Krempski, J.W.; Raffel, C.; Shelton, S.E.; Soeffker, D.; Zollman, P.; Federspiel, M.J.; et al. Toxicology study of repeat intracerebral administration of a measles virus derivative producing carcinoembryonic antigen in rhesus macaques in support of a phase I/II clinical trial for patients with recurrent gliomas. Hum. Gene Ther. 2008, 19, 690-698. [CrossRef]

146. Völker, I.; Bach, P.; Coulibaly, C.; Plesker, R.; Abel, T.; Seifried, J.; Heidmeier, S.; Mühlebach, M.D.; Lauer, U.M.; Buchholz, C.J. Intrahepatic application of suicide gene-armed measles virotherapeutics: A safety study in transgenic mice and rhesus macaques. Hum. Gene Ther. Clin. Dev. 2013, 24, 11-22. [CrossRef]

147. Lal, S.; Peng, K.W.; Steele, M.B.; Jenks, N.; Ma, H.; Kohanbash, G.; Phillips, J.J.; Raffel, C. Safety Study: Intraventricular Injection of a Modified Oncolytic Measles Virus into Measles-Immune, hCD46-Transgenic, IFN $\alpha$ Rko Mice. Hum. Gene Ther. Clin. Dev. 2016, 27, 145-151. [CrossRef]

148. Russell, S.J.; Federspiel, M.J.; Peng, K.W.; Tong, C.; Dingli, D.; Morice, W.G.; Lowe, V.; O'Connor, M.K.; Kyle, R.A.; Leung, N.; et al. Remission of disseminated cancer after systemic oncolytic virotherapy. Mayo Clin. Proc. 2014, 89, 926-933. [CrossRef]

149. Ungerechts, G.; Bossow, S.; Leuchs, B.; Holm, P.S.; Rommelaere, J.; Coffey, M.; Coffin, R.; Bell, J.; Nettelbeck, D.M. Moving oncolytic viruses into the clinic: Clinical-grade production, purification, and characterization of diverse oncolytic viruses. Mol. Ther. Methods Clin. Dev. 2016, 3, 16018. [CrossRef]

150. Langfield, K.K.; Walker, H.J.; Gregory, L.C.; Federspiel, M.J. Manufacture of measles viruses. Methods Mol. Biol. 2011, 737, 345-366. [CrossRef]

151. Loewe, D.; Dieken, H.; Grein, T.A.; Weidner, T.; Salzig, D.; Czermak, P. Opportunities to debottleneck the downstream processing of the oncolytic measles virus. Crit. Rev. Biotechnol. 2020, 40, 247-264. [CrossRef]

152. Loewe, D.; Häussler, J.; Grein, T.A.; Dieken, H.; Weidner, T.; Salzig, D.; Czermak, P. Forced Degradation Studies to Identify Critical Process Parameters for the Purification of Infectious Measles Virus. Viruses 2019, 11, 725. [CrossRef]

153. Baldo, A.; Galanis, E.; Tangy, F.; Herman, P. Biosafety considerations for attenuated measles virus vectors used in virotherapy and vaccination. Hum. Vaccin. Immunother. 2016, 12, 1102-1116. [CrossRef]

154. Leber, M.F.; Hoyler, B.; Prien, S.; Neault, S.; Engeland, C.E.; Förster, J.M.; Bossow, S.; Springfeld, C.; von Kalle, C.; Jäger, D.; et al. Sequencing of serially passaged measles virus affirms its genomic stability and reveals a nonrandom distribution of consensus mutations. J. Gen. Virol. 2020, 101, 399-409. [CrossRef]

155. Ribas, A.; Dummer, R.; Puzanov, I.; VanderWalde, A.; Andtbacka, R.H.I.; Michielin, O.; Olszanski, A.J.; Malvehy, J.; Cebon, J.; Fernandez, E.; et al. Oncolytic Virotherapy Promotes Intratumoral T Cell Infiltration and Improves Anti-PD-1 Immunotherapy. Cell 2018, 174, 1031-1032. [CrossRef] 